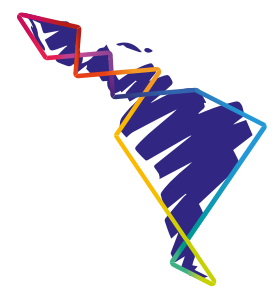

\title{
Vuelta a la patria en tiempos desesperados: imaginarios sociales en torno a los retornados a Petare-Venezuela en época de pandemia
}

\author{
Return to the homeland in \\ desperate times: social imaginaries \\ around those returned to Petare- \\ Venezuela in time of pandemic
}

\section{Retorno à pátria em tempos desesperados: imaginários sociais em torno dos que voltaram para Petare-Venezuela em tempo de pandemia}

Dra. Suzuky Margarita Gómez Castillo'

Dr. Diógenes José Molina Castro²

Recibido: 13-9-2019 - Aceptado: 13-5-2021

1 Doctora en Educación Ambiental por Instituto Pedagógico de Caracas adscrito a la Universidad Pedagógica Experimental Libertador, Magister Scientiarum en Historia de Venezuela por la Universidad Central de Venezuela, Especialista en Planificación y Evaluación de la Educación por la Universidad Santa María de Caracas. Profesora del Departamento de Práctica Profesional del Pedagógico de Miranda José Manuel Siso Martínez adscrito a la Universidad Pedagógica Experimental Libertador, Venezuela. Correo electrónico: suzukygomez@gmail.com (iD https://orcid.org/0000-0002-4421-6730

2 Doctor, Magister Scientiarum y Especialista en Historia, por la Universidad Santa María de Caracas. Profesor Jubilado del Departamento de Geografía e Historia del Instituto Pedagógico de Miranda José Manuel Siso Martínez adscrito a la Universidad Pedagógica Experimental Libertador, Venezuela. Director-Decano del Instituto Universitario de Tecnología Tomás Lander e investigador titular en la Escuela Iberoamericana Cooperativa de Estudios Avanzados. Correo electrónico: diogenesjmolina@yahoo.com, (D) https://orcid. org/0000-0002-8570-7712 


\title{
Resumen
}

El propósito de esta investigación es caracterizar los imaginarios sociales que emergen de los relatos de vida, alrededor de los retornados al sector El Carpintero de Petare en Miranda-Venezuela, escenario de la investigación, durante época de pandemia. Se está ante un tipo de investigación cualitativa, desde el paradigma interpretativo con enfoque biográfico y diseño narrativo, desde la perspectiva del relato de vida. Entre los postulados teóricos trabajados cabe mencionar; La institución imaginaria de la sociedad (Castoriadis, 1993), Historia de Vida (Ferraroti, 2008) y la teoría del déficit autocuidado (Orem, 1991). Dentro de los resultados cabe mencionar que las políticas públicas de prevención ante la COVID-19 no pueden plantearse bajo condiciones que estigmaticen, produzcan temor y recelo en la colectividad. Esto no puede considerarse una forma productiva de controlar los contagios.

Palabras clave: Imaginarios sociales, pandemia, retornados a Venezuela.

\begin{abstract}
The purpose of this research is to characterize the social imaginaries that emerge from the life stories, around the returnees to the El Carpintero de Petare sector in Miranda-Venezuela, the scene of the investigation, during the time of the pandemic. The present work is a type of qualitative research, from the interpretive paradigm with a biographical approach and narrative design, from the perspective of the life story. Among the theoretical postulates treated, it is worth mentioning; The imaginary institution of society (Castoriadis, 1993), Life History (Ferraroti, 2008) and Self-care deficit theory (Orem, 1991). Among the results, it is worth mentioning that public prevention policies against COVID-19 cannot be proposed under conditions that stigmatize and produce fear and suspicion in the community. This cannot be considered a productive way to control infections.
\end{abstract}

Keywords: Social Imaginaries; Pandemic; Returned to Venezuela.

\section{Resumo}

O objetivo desta pesquisa é caracterizar os imaginários sociais que emergem das histórias de vida, em torno dos retornados ao setor El Carpintero de Petare em Miranda-Venezuela, cenário da investigação, durante o período da pandemia. Trata-se de um tipo de pesquisa qualitativa, partindo do paradigma interpretativo com abordagem biográfica e desenho narrativo, na perspectiva da história de vida. Dentre os postulados teóricos trabalhados, vale citar; a instituição imaginária da sociedade (Castoriadis, 1993), a História de Vida (Ferraroti, 2008) e a teoria do déficit de autocuidado (Orem, 1991). Dentre os resultados, vale ressaltar que políticas públicas de prevenção à COVID-19 não podem ser propostas em condições que estigmatizem e gerem medo e desconfiança na comunidade. Isso não pode ser considerado uma forma produtiva de controlar infecções.

Palavras-chave: Imaginários Sociais; Pandemia; Retorno à Venezuela. 


\section{Introducción}

Las carencias estructurales del sistema económico venezolano y la recurrente confrontación política son señaladas, entre otras, como causas de exclusión de un amplio sector de la sociedad que no consigue un empleo con las condiciones laborales mínimas para poder obtener una calidad de vida digna. Esto provoca que un porcentaje significativo de venezolanos elijan emigrar del país en busca de nuevas oportunidades con el ideal de obtener un mejor modelo de vida. Como resultado, según datos de la Agencia de la ONU para refugiados (ACNUR) y la Organización Internacional para la Migraciones (OIM), se ha constituido una comunidad de migrantes y refugiados de Venezuela en el mundo que para 2019 superó los cuatro millones. Sobre la base de estas consideraciones se desglosan las cifras de ACNUR (2019):

Los países latinoamericanos acogen la gran mayoría de venezolanos, con Colombia de 1,3 millones, seguido por Perú, con 768.000, Chile 288.000, Ecuador 263.000, Argentina 130.000 y Brasil 168.000. México y los países de América y el Caribe también albergan un gran número de refugiados y migrantes de Venezuela. (p. 3)

Como consecuencia, con su labor se estima que estos migrantes apuntalan la economía de muchas familias venezolanas. Estos aportes financieros son una de las bases que estimula el comercio y contribuye a mejorar la salud, la educación y la vivienda entre otros aspectos. Por ello el rol desempeñado por migrantes en la economía nacional es primordial y se debe valorar en su justa medida.

No obstante, motivado a las duras políticas migratorias en los países de tránsito y destino, y al escenario mediático que representa a las poblaciones migrantes como una amenaza y un aumento en los problemas de los países receptores, cuando los medios hacen uso frecuente e insistente de determinados términos genéricos en titulares como: "Cerca de 5.000 personas huyen de Venezuela diariamente"(según Watson, 2018) o "Cientos de peruanos marcharon en rechazo a los migrantes venezolanos"(Voz de América, 2020), es muy posible que la sola presencia de un venezolano, en los escenarios que fuese, lleve, de forma mecánica, a dirigir una asociación ineludible con esos contenidos mediáticos. Estos mismos acaban promoviendo un estigma en torno a los connacionales; quienes se han transformado en un grupo que afronta episodios de vulnerabilidad y riesgo. Sobre lo anterior, Sáez (2005) comenta:

Los medios no solo median entre la realidad y la experiencia individual o colectiva, sino que al mismo tiempo son protagonistas de esta mediación a través de las distintas selecciones que llevan a cabo para enmarcar un hecho noticioso. En función 
de este doble rol es que cabe exigir de ellos la satisfacción de unos mínimos de responsabilidad social relacionados con informar sobre la realidad de una manera más o menos cercana a ella en términos de representar adecuadamente los matices que ésta posee, hacer circular información que contribuya a la toma de decisiones de los ciudadanos, siendo veraces pero al mismo tiempo evitar transmitir la imagen de una realidad abrumadora e incontrolable... (p. 21)

Aunado a esto, la población migrante ve incrementarse sus problemas debido a la pérdida del empleo. Se le imposibilita salir a cumplir sus jornadas laborales diarias, además de que debe afrontar la carencia de programas de atención en el proceso social del trabajo, la separación familiar y la soledad por la pandemia en las diferentes ciudades de América. En este sentido, las jurisdicciones de los países de tránsito y destino no detienen su política, seguimiento y detención. Al respecto, el Centro de Derechos Humanos de la UCAB (CDH-UCAB, 2020) refiere:

El fenómeno del retorno es consecuencia de las políticas de prevención y contención de la pandemia, que ha tenido el confinamiento como principal estrategia. Ocupándose principalmente en el sector informal, muchos migrantes y refugiados se encontraron de un día para otro sin ingresos, ni vivienda, ni alimentos, ni redes de apoyos familiares o institucionales, por lo que el regreso a Venezuela pareció para algunos la única opción. (p.1)

Considerando el contexto recientemente planteado, el retorno voluntario de miles de connacionales que les resulta inviable quedarse en los países de acogida, se pronostica una migración inversa. Esta insta de estrategias y políticas públicas que retomen el papel primordial del Estado y el diseño de un plan nacional con modificaciones profundas para subsanar las fallas estructurales, promotoras del éxodo venezolano. Asimismo, se requiere que los integrantes de las organizaciones encargadas de recibir a los migrantes retornados se formen con el objetivo de subsanar el déficit de autocuidado, tal como lo señala Dorothea Orem (1991) que pudiera generar un incremento de casos por COVID-19, así como el rechazo en las diversas comunidades-destino. En este sentido, Alvarado (2020) acota:

[Al retornado] Se les pretende culpabilizar de la expansión del coronavirus. En cada reporte oficial hay un señalamiento hacia ellos e incluso se llegó a afirmar que eran enviados a propósito a Venezuela por gobiernos enemigos...De esta manera, se les expone al rechazo en las comunidades donde llegan y se produce riesgo a su integridad física... (p. 2)

También, cabe destacar que el contexto de tensión y violencia estimulado por la estigmatización de las personas retornadas, la carencia de información, la propagación 
de mensajes falsos o distorsionados en las redes sociales, encargadas de incitar tanto a la violencia física como a la simbólica, no solo se reservó para los migrantes. Se han extendido tanto a los retornados como a las víctimas del contagio.

\section{Aproximación al problema}

La época de pandemia ha provocado el regreso de migrantes, al punto que, más de 90000 connacionales han regresado al país por diferentes medios (caminando, en mula, en camiones, autobuses, en vuelos humanitarios, pasando por veredas improvisadas (trochas), o negociando su transporte en las alcabalas, etc.). Algunos de estos retornados, cuyo paso fue ilícito, han logrado llegar a sus comunidades de residencia. Tal es el caso de nuestros informantes clave, quienes viven en el sector Carpintero, parroquia Petare del municipio Antonio José de Sucre en el estado Miranda-Venezuela, donde, según la impresión de sus vecinos, junto a sus familiares se han convertido en factores de riesgo, de incomodidad y perjuicio, situación que ha llevado a las líderes del Consejo Comunal a tomar acciones en favor de observar el orden y hacer cumplir las medidas sanitarias recomendadas por el Estado Mayor de Salud para la COVID-19.

En consecuencia, esta investigación procura conocer cuáles son los imaginarios sociales en torno estos retornados a Petare que se negaron a aceptar los protocolos de atención y reintegración, a partir de un diagnóstico social y sanitario donde inicialmente se detecta déficit de autocuidado. También, se hace necesario estudiar los imaginarios de otros actores sociales y de las líderes comunales, quienes declaran un estado de alerta comunitario, con el propósito de fomentar espacios de intercambio y cooperación intercomunitarios, establecer una cuarentena domiciliaria para los retornados con la intensión de enfrentar un posible contagio y otros problemas sociales que pudieran generar la incomunicación y resultar en acciones violentas, de parte de grupos inconformes y aterrorizados.

No obstante, a los acontecimientos de Petare, un alto porcentaje de retornados cuya repatriación se ha realizado de manera lícita y observando los protocolos de seguridad, han sido referidos a los Puntos de Atención Social Integral (PASI). Sin embargo, algunos de estos ciudadanos señalan las fallas en estos ambientes, destacan entre las anormalidades el incumplimiento de los estándares establecidos por la Organización Mundial de la Salud (OMS), el cual reza la importancia de evitar aglomeraciones y de aplicar medidas de distanciamiento social de por lo menos un metro entre una persona y otra, situaciones que están en contra del derecho humano a la salud, por tales razones el CDH-UCAB (2020) refiere: 
... los retornados encontraron en los llamados Puntos de Atención Social Integral (PASI) una muestra de lo que les deparaba el país: alimentos en mal estado, falta de agua, de combustible y de servicios médicos, además de militarización y represión. Las primeras expresiones de rechazo al retornado provinieron del fiscal...quien los calificó de "karma", seguido por la ministra... quien los llamó fascistas y golpistas camuflados. Poco después varios funcionarios...de forma deplorable afirmaron que los retornados eran armas biológicas enviadas por el gobierno de Colombia para contaminar a Venezuela. (p. 3)

Es evidente, entonces, que en el país se han instalado imaginarios sociales excluyentes, discriminatorios, y estigmatizados. Todos ellos desconocen las contribuciones de los retornados y promueven tratos inhumanos e indignos que, con el transcurrir del tiempo y con el refuerzo de la recurrencia, optan por verse con normalidad. Sin embargo, también los retornados son recibidos en sus comunidades con resquemor y recelo, su paso por un PASI no los exime de ser asociados con el virus. En este tenor, Palma (2020) comenta:

Todo comenzó hace unos meses al hacer pública la diferencia entre contagios 'importados' y 'comunitarios' por covid-19 para trazar el comportamiento del virus. A simple vista, este parecía un tecnicismo estadístico. Sin embargo, con el paso de los días, este se convirtió en la base de un discurso estigmatizante que hoy replican muchos medios de comunicación y ciudadanos desde diferentes esquinas políticas. Líderes del entorno nacional y local han repetido hasta la saciedad que los migrantes retornados han 'importado' el virus desde otros países, principalmente desde Colombia y Brasil. Su credibilidad ha venido creciendo, en tanto el número de contagios en estos países ha aumentado. Al tiempo, esto ha justificado el crecimiento de la vigilancia oficial y ciudadana sobre los retornados, en detrimento de su ya vulnerable situación.(p. 3)

El gobierno de Venezuela realiza esfuerzos para contener y prevenir la trasmisión de la COVID-19, y ha tomado medidas importantes. Aunque, se deben apuntalar aspectos básicos para la correcta atención de los numerosos grupos de personas que retornan. Ante los retos reales y emergentes de la actual situación migratoria, que presume continuará dando paso al regreso de muchos compatriotas y con ello la proliferación de medidas para subsanar el déficit de autocuidado, surge la siguiente interrogante:

¿Qué imaginarios sociales emergen de los relatos de vida en torno a los retornados al sector El Carpintero de Petare en época de pandemia? 


\section{Supuesto de la investigación}

Caracterizar los imaginarios sociales que emergen en torno a los retornados al sector El Carpintero de Petare en época de pandemia.

\section{Categorías y subcategorías apriorísticas}

Las categorías y subcategorías apriorísticas son aquellas cimentadas previas al proceso de compilación de los datos, es decir, surgen desde el proceso mismo de investigación. En este sentido, Cisterna (2007) plantea:

El término de "apriorístico" [objetivador] que se utiliza aquí para adjetivar a las categorías y subcategorías descritas anteriormente, significa que éstas son construidas por el investigador antes de realizar el proceso de recogida de la información, y por ello se contraponen a las llamadas "categorías emergentes" [sensibilizadoras/subjetivas], que son aquellas que surgen en el proceso mismo de la investigación. (p.15)

Estos temas brotan de la búsqueda a partir de la formulación de los objetivos generales, surgidos, quizás, de las interrogantes (preguntas) de la indagación en término de fines (intensiones o metas), como también sucede con los objetivos específicos, premisas, supuestos y/o ejes temáticos, que desglosan y operacionalizan los primeros.

Señalado en términos precisos, estos temas se concretan en el diseño de indagación por intermedio de las reconocidas categorías apriorísticas, quienes denotan un tema en sí mismo y de su desglose en subcategorías las cuales describen dicho tema en microaspectos. Según Herrera, Guevara y Munster (2015), estas categorías constituyen "... la expresión orgánica que orienta y direcciona la construcción de los instrumentos recopiladores de la información..." (p. 7). Cabe destacar de nuevo la postura de Cisterna (2020), quien en este tenor defiende:

La ventaja de las categorías y subcategorías apriorísticas por sobre las categorías emergentes radica en que el uso de las primeras permite centrar la investigación, reduciendo el riesgo de la dispersión, pues el investigador articula su proceso indagativo en aquello que efectivamente le es útil e indispensable para sus propósitos. Una investigación cualitativa puede perfectamente contar con categorías y subcategorías tanto apriorísticas como emergentes. Las categorías y subcategorías deben ser conceptualizadas, es decir, hay que explicar cómo se entienden al interior de la investigación. Para ello, también resulta fundamental recurrir al marco teórico... (p.16) 
Se debe admitir cierta semejanza con la función que tienen las variables y los indicadores en los modelos cualitativos, sin embargo son disímiles, ya que estas categorías y subcategorías, según Herrera y otros (2015) “...por muy apriorístico que sea el diseño" (p. 8), no exceptúan la posibilidad de que el investigador, a partir de su subjetividad, incorpore aspectos emergentes emanados del propio proceso indagatorio, lo que no sucede en los primeros.

Considerando lo antes planteado, en los siguientes cuadros y en el gráfico se detalla una síntesis del tema-problema a investigar a partir de las categorías y subcategorías apriorísticas, relacionado con los imaginarios sociales de los retornados a Venezuela en clave a la teoría de autocuidado en época de pandemia:

\section{Cuadro 1}

Síntesis del desarrollo de la situación problemática de la investigación

\begin{tabular}{|c|c|c|c|}
\hline Interrogante & $\begin{array}{l}\text { Supuesto de la } \\
\text { investigación }\end{array}$ & $\begin{array}{l}\text { Categorías } \\
\text { apriorísticas }\end{array}$ & $\begin{array}{l}\text { Subcategorías } \\
\text { apriorísticas }\end{array}$ \\
\hline $\begin{array}{l}\text { ¿Qué imaginarios } \\
\text { sociales emergen } \\
\text { en torno a los } \\
\text { retornados al sector } \\
\text { El Carpintero de } \\
\text { Petare en época de } \\
\text { pandemia? }\end{array}$ & $\begin{array}{l}\text { Caracterizar } \\
\text { los imaginarios } \\
\text { sociales que } \\
\text { emergen en torno } \\
\text { a los retornados } \\
\text { al sector El } \\
\text { Carpintero de } \\
\text { Petare en época de } \\
\text { pandemia. }\end{array}$ & $\begin{array}{l}\text { Imaginarios } \\
\text { sociales de } \\
\text { retornados } \\
\text { Época de pandemia }\end{array}$ & $\begin{array}{l}\text { Imaginario social } \\
\text { Retornado } \\
\text { COVID } 19 \\
\text { Pandemia } \\
\text { Cuarentena }\end{array}$ \\
\hline
\end{tabular}

Nota. Cuadro elaborado a partir de los intereses de investigación de los autores 


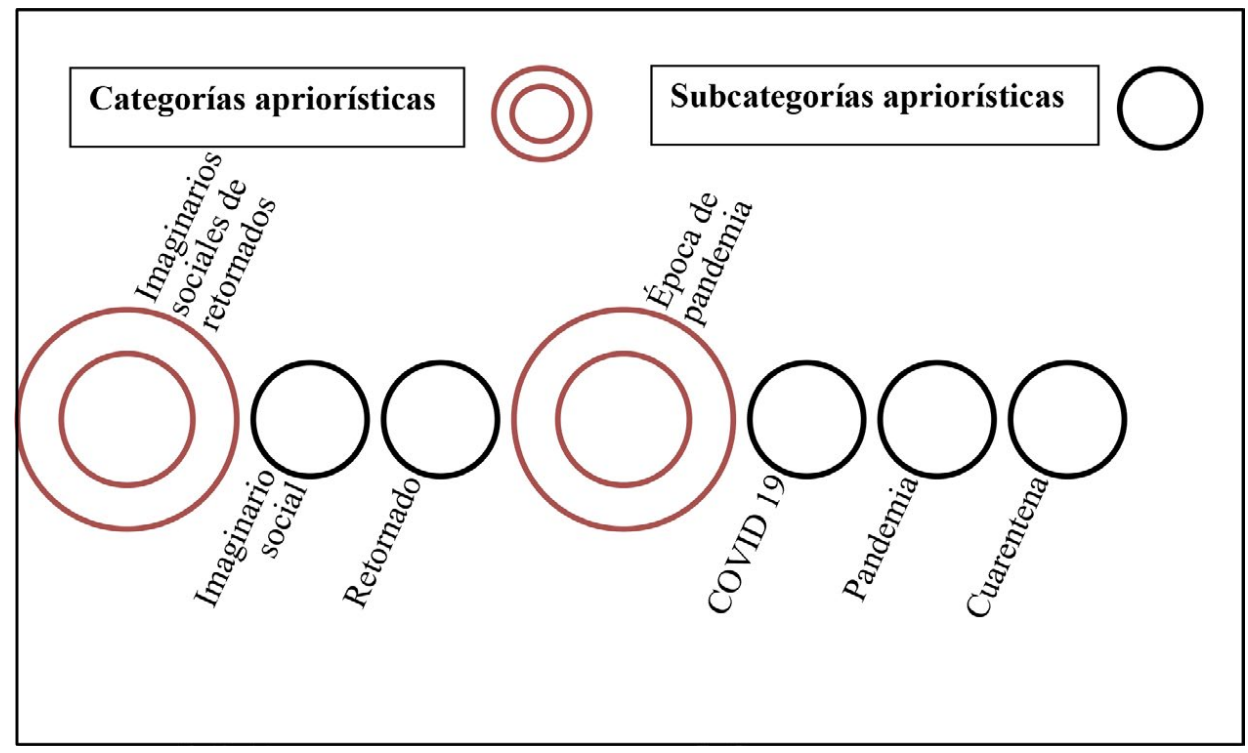

Gráfico 1. Categorías apriorísticas y subcategorías apriorísticas. Elaborado por los investigadores.

\section{Cuadro 2}

Definición conceptual de las categorías y subcategorías apriorísticas

\begin{tabular}{|c|c|c|c|}
\hline $\begin{array}{l}\text { Categorías } \\
\text { apriorísticas }\end{array}$ & Definición conceptual & $\begin{array}{c}\text { Subcategorías } \\
\text { apriorísticas }\end{array}$ & Definición conceptual \\
\hline $\begin{array}{l}\text { Imaginarios } \\
\text { sociales de los } \\
\text { retornados }\end{array}$ & $\begin{array}{l}\text { Se refiere a la creación } \\
\text { constante (social, } \\
\text { histórica, psíquica) } \\
\text { de figuras, formas, } \\
\text { imágenes, en y sobre } \\
\text { las personas que han } \\
\text { decidido regresar a } \\
\text { Venezuela y a través } \\
\text { de la cuales se intenta } \\
\text { interpretar sus historias } \\
\text { y contextualizar sus } \\
\text { realidades. }\end{array}$ & Imaginario social & $\begin{array}{l}\text { Se refiere a los } \\
\text { productos de la } \\
\text { función significante, } \\
\text { a ese imaginario que } \\
\text { Castoradis (1975) } \\
\text { llama el imaginario } \\
\text { efectivo: mitos, } \\
\text { ideologías, creencias, } \\
\text { religiones, paradigmas } \\
\text { interpretativos del } \\
\text { mundo. } \\
\text { Se refiere a quienes } \\
\text { regresan a su lugar } \\
\text { de origen después de } \\
\text { vivir durante un lapso } \\
\text { prolongado en otro } \\
\text { país. }\end{array}$ \\
\hline
\end{tabular}




\begin{tabular}{|c|c|c|c|}
\hline Época de pandemia & $\begin{array}{l}\text { Época caracterizada } \\
\text { por la presencia del } \\
\text { COVID-19 y donde } \\
\text { se han generado } \\
\text { medidas de salud para } \\
\text { prevenir el contagio } \\
\text { y la expansión del } \\
\text { virus, sustentadas en } \\
\text { una cuarentena social, } \\
\text { colectiva y voluntaria } \\
\text { como estrategia del } \\
\text { protocolo nacional en } \\
\text { Venezuela. }\end{array}$ & $\begin{array}{l}\text { Pandemia } \\
\text { Cuarentena }\end{array}$ & $\begin{array}{l}\text { Se refiere a una } \\
\text { enfermedad infecciosa } \\
\text { ocasionada por } \\
\text { el coronavirus que } \\
\text { se ha manifestado y } \\
\text { extendido actualmente. } \\
\text { Se refiere una } \\
\text { enfermedad epidémica } \\
\text { que se extiende } \\
\text { por varios países } \\
\text { o que ataca a una } \\
\text { gran porción de los } \\
\text { individuos de una } \\
\text { localidad o región. } \\
\text { Se refiere al } \\
\text { término para } \\
\text { puntualizar el } \\
\text { aislamiento de las } \\
\text { personas durante un } \\
\text { lapso no específico } \\
\text { como método para } \\
\text { evitar o limitar el } \\
\text { peligro de extender } \\
\text { una enfermedad. }\end{array}$ \\
\hline
\end{tabular}

Nota. Cuadro elaborado con datos tomados de "Fundamentos teórico epistemológicos de los imaginarios sociales" por J. Cegarra, 2012, Cinta Moebio, 43, 1-13. Diccionario médico-biológico, histórico y etimológico, de Dicciomed, 1-4

\section{Marco referencial}

\section{El imaginario social}

A partir de la necesidad de recuperar al ser histórico-social, Cornelius Castoradis innova (1993), la forma de pensar la filosofía occidental cuando enfrenta las respuestas tradicionales del estructuralismo y funcionalismo sobre la base de dos tópicos, por una parte lo que mantienen unidad a la sociedad y por la otra la causa de la variación de la temporalidad. En este tenor, también manifiesta que la sociedad se autoinstituye, a partir de un conjunto de prácticas y discursos que validan y reafirman la correspondencia, equivalencia y entendimiento entre las sociedades.

Para esclarecer lo histórico-social, Castoradis (1975) inicia creando una separación de las dimensiones que se presentan en este ser: la lógica heredada (identitario-conjuntista) y el imaginario social. La primera se ha predominado con el pasar del 
tiempo: esta concibe y representa al ser como determinado (ser-determinado), la existencia determinada y el decir determinado (decir-determinado). Cabe mencionar, que el producto representativo de la lógica conjuntista son las matemáticas, que se han extrapolado en todos los contextos del decir y representar social (legein) y del hacer social (teukhein). Mientras que el segundo (imaginario social) se reencuadra en lo indeterminado, en lo inconsciente, es decir en la imaginación

En pocas palabras, a partir de esta dimensión se construye e instituye una manera de repensar la sociedad, no desde la identidad y lo definible, sino desde la creación indeterminada e inacabable de esta misma, de sus productos, sus significados, sentidos y las prácticas que convergen esos productos. Esta dimensión es el soporte indescifrable sobre el cual descansa toda ella. Es la perspectiva imprevisible que no ocurre directamente y que permite concebir la relativa indeterminación de la institución y de los significados sociales. Es la respuesta a las diferencias que conviven en una sociedad. Todo esto envuelto en un imaginario explicado por Castoradis (1993) de la siguiente manera:

El imaginario del que hablo no es imagen de. Es creación incesante y esencialmente indeterminada (social, histórica y psíquica) de figuras/formas/imágenes, y solo a partir de estas puede tratarse de "algo". Lo que llamamos "realidad" y "racionalidad" son obras de esta creación. (p. 29)

Sin embargo, para Castoradis el aporte que el ideario heredado (dimensión identitaria-conjuntista) ha ofrecido a lo histórico-social es fundamentalmente negativo, ya que es una respuesta a las restricciones e imposiciones en la manera de pensar y de la expresión de los obstáculos que ha tenido que enfrentar. El ser histórico-social no pude entenderse solo bajo la lógica de los conjuntos, ya que esta no acepta las explicaciones deterministas que intentan apartarla, fijarla o fragmentarla en términos definitivos o absolutos. Sobre esto, Castoradis indica (1975): “... como un magma, como un magma de magmas, organización de una diversidad no susceptible de ser reunida en un conjunto, ejemplificada por lo social, lo imaginario y lo inconsciente..." (p. 34). En igual forma, no es posible apartar lo histórico de lo social, ambos son posibilidad y coexistencia.

Esto no significa que todo sea magma y caos indeterminado, contrariamente, como las personas establecieron canales de comunicación, entendimiento o dieron continuidad a determinadas prácticas sociales. Lo que nos advierte Castoradis (1975) cuando discute es que el ser histórico-social se forma y se nutre con la imaginación, la creación y la indeterminación del ser, es decir el magma de significaciones sociales puede emerger o construir organizaciones conjuntistas, tal como señala González (2011, p. 3). Al respecto, la institución de la sociedad es 
siempre institución de un magma de significaciones, esto es posible gracias a la instrumentación de la sociedad en dos instituciones que maniobran a partir de la lógica identitaria-conjuntista (legein y teukhein)- Sobre ello, González (2011) acota:

El "legein" [distinguir-elegir-poner-reunir-contar-decir] es el que encarna y da existencia a la dimensión identitaria-conjuntista del lenguaje o representar social, es a partir de él que el lenguaje se convierte en código. Por su parte, el "teukhein" [reunir-adaptar-fabricar-construir] hace lo mismo que el legein, pero esto sucede en el ámbito del hacer social. Ambas instituciones se implican recíprocamente y, asimismo, son creaciones absolutas de lo histórico-social, es decir, las dos operan desde la dimensión de lo indeterminable y lo imaginario, y se prestan a la lógica identitaria-conjuntista para instituirse en el mundo social... (p. 4)

De igual forma, puede señalarse que tanto la institución del legein como del teukhein son manifiestamente un canal de apertura indeterminada de significados, ya que, si bien organizan y construyen la sociedad, asimismo le proporcionan los recursos para destruir los esquemas existentes y, por lógica, perturbar su equivalencia y orden social. En este sentido, Castoradis (1997) explica:

Hablo de autocreación, no de autorganización. En el caso de la sociedad, no encontramos un ensamblado de elementos preexistentes, cuya combinación podría haber producido cualidades nuevas o adicionales del todo. Los cuasi (o pseudo) "elementos" de una sociedad son creados por la sociedad misma... (p. 5).

En resumen, Castoradis señala que las dos instituciones son compatibles con la lógica identitaria o de conjuntos, esto no significa que las dos son creaciones continuamente determinables en y por significaciones imaginarias sociales en el ser histórico-social.

\section{Teoría general del déficit autocuidado}

La teoría general del déficit de autocuidado originalmente es un postulado propuesto por Dorothea E. Orem (1991), y compuesta por tres teorías vinculadas entre sí: teoría de autocuidado, teoría del déficit autocuidado y teoría de los sistemas de enfermería. No obstante, para esta investigación se realizó una modificación de la estructura de la teoría general sustituyéndose la teoría de enfermería por la declaratoria de estado de alarma para atender la emergencia sanitaria del coronavirus (COVID-19) por decreto N. ${ }^{\circ} 4.198$ y que reposa en la Gaceta Oficial de la República Bolivariana de Venezuela (2020), implementada a través de la cuarentena colectiva y social de ciudadanos y ciudadanas como una estrategia para la mitigación de contagios. Es importante esclarecer que a través de los componentes de esta teoría se intentó, asimismo, comprender los niveles de acatamiento de la 
normativa sanitaria de responsabilidad social (2020) por parte de los retornados y de otros vecinos del sector El Carpintero de Petare y que se desarrollarán en el apartado correspondiente a la discusión de los hallazgos.

No obstante, y retomando a Orem (1991) en su postulado, resulta importante señalar que ella aborda al individuo de una forma integral con el propósito situar los cuidados básicos como el centro de ayuda al ser humano que le contribuye a vivir cómodamente durante más tiempo, es decir, se persigue mejorar la calidad de vida del individuo. De igual forma, define la necesidad de actuar por la persona con alguna discapacidad, apoyarla, ofrecerle apoyo para logre accionar por sí misma con el propósito de ayudar al individuo a mantenerse por sus propios medios y que pueda emprender acciones de autocuidado que le lleven a preservar la salud y la vida, tal como lo señalan Prado, González, Paz y Romero (2014, p. 840). A su vez, los autores referidos proponen un concepto básico de autocuidado a partir de la propuesta de Orem (1991), y lo caracterizan "y desarrollo posteriormente como el conjunto de acciones intencionadas que ejecuta una persona para dominar los elementos externos e internos, que pueden poner en riesgo su vida" (p.841). El autocuidado es una conducta que consiste en llevar a cabo la práctica de actividades que las personas adultas o quienes están en ese proceso, inician y llevan a cabo en determinados lapsos, con el objeto de mantener un funcionamiento activo y saludable, dando prosecución al desarrollo personal y al bienestar de las personas. Sobre este tema, obsérvese el gráfico 2:

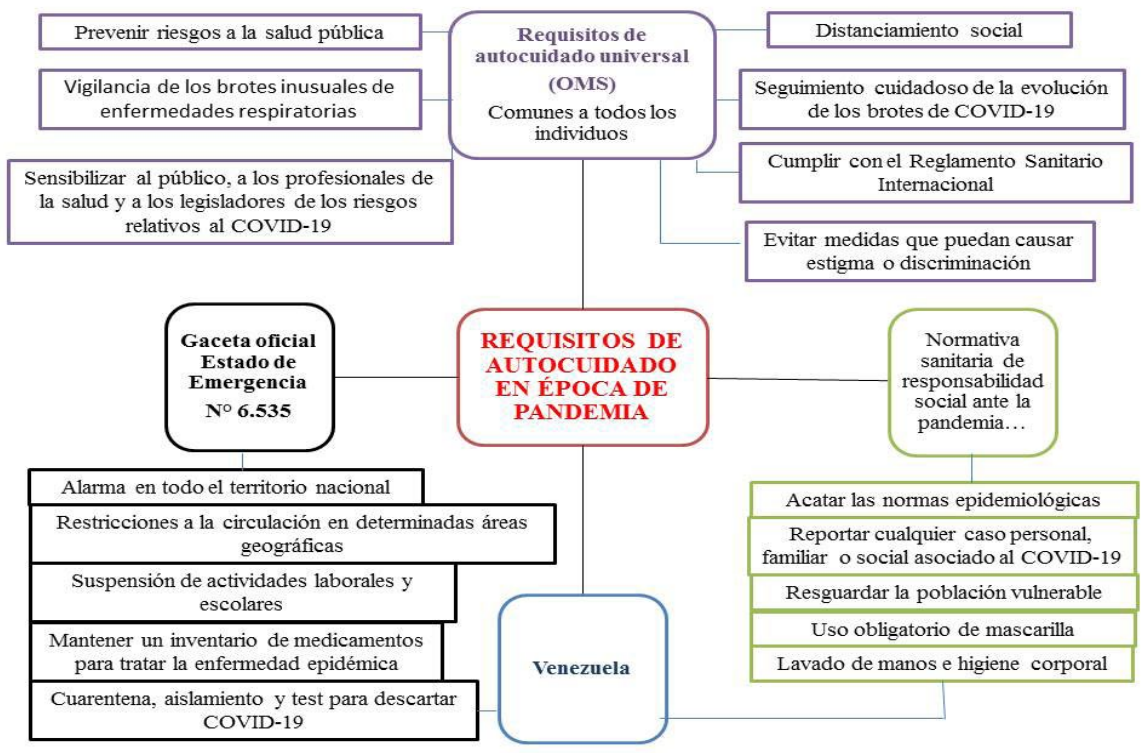

Gráfico2. Requisitos de autocuidado en época de pandemia. Elaborado por los investigadores. 
En el gráfico puede observarse un esbozo de las actividades de autocuidado a partir de un ente (OMS, 2020) cuyo fin, con su reglamento y sus indicaciones, es contribuir a preservar la vida como la conocemos en el mundo global, asimismo, se observa cómo Venezuela asume estas sugerencias y las adapta a los contextos nacionales y locales a través de la aplicación de los artículos de la Constitución de la República, de los decretos, resoluciones y normativas.

No obstante, imponer el autocuidado no dará los resultados esperados, solo se hará efectivo a través de un proceso se educación y sensibilización donde los adultos estarán en situación de aprendizaje y observen cómo son afectadas sus vidas y la de sus familias por la pandemia. Todo se trastoca y se intervienen sus creencias, cultura, hábitos familiares y sociales. Con estos requisitos de autocuidado como la edad, se observa que el desarrollo y el estado de salud puede afectar la capacidad de ejecutar actividades de autocuidado. En la empresa, para conseguir sostener el bienestar, la salud y el desarrollo de todos los individuos se deben cumplir unos requisitos fundamentales, soportados en superar el déficit de autocuidado. Este parece incrementarse con las cifras de contagiados de COVID-19. Obsérvese el gráfico 3.

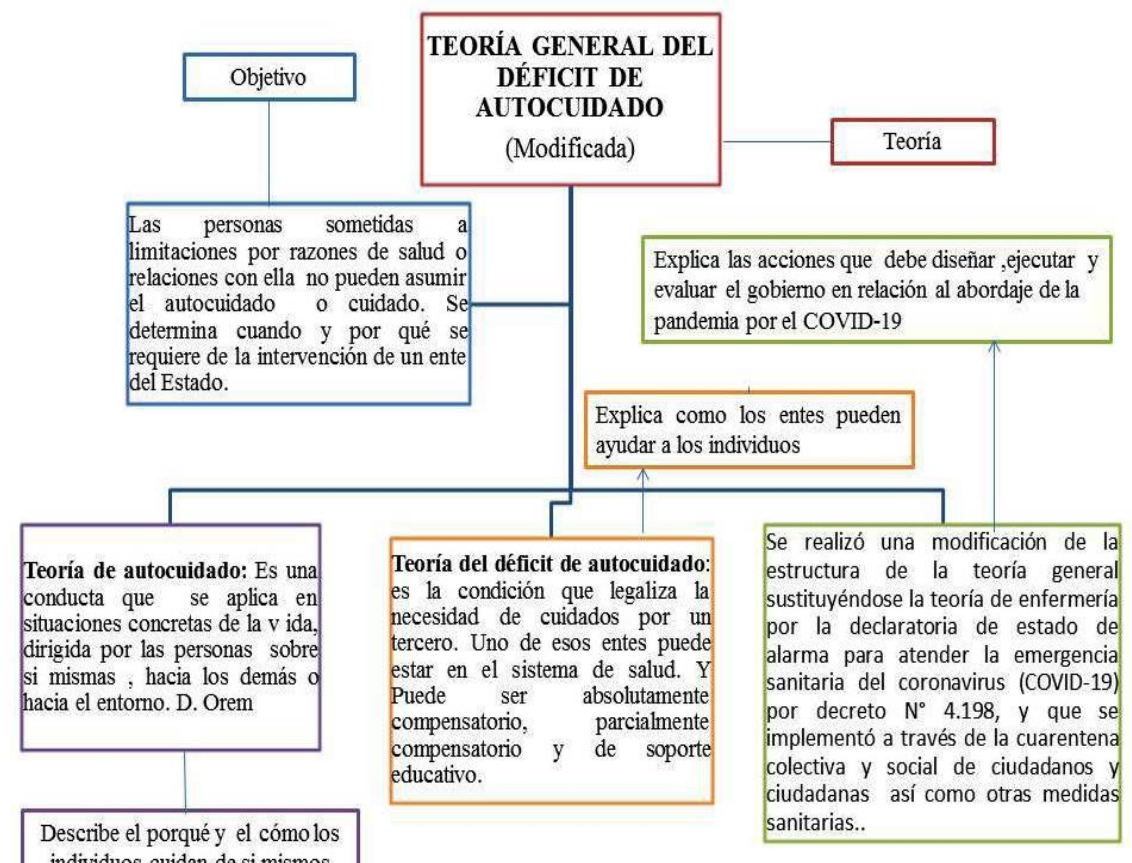

Gráfico. 3. Modificación y adaptación de la teoría de déficit de cuidado de Dorothea Orem (1991) para la investigación. Elaborado por los investigadores. 
La construcción de los conceptos de autocuidado, déficit de autocuidado y las actividades de autocuidado ofrecidas por los entes gubernamentales, brindan el soporte para comprender los requisitos de la acción y sus límites. Considerando el autocuidado como una función reguladora del individuo, que deben voluntariamente llevar a cabo, por sí mismas, una actividad del ser humano, aprendida y dirigida hacia un objetivo, una conducta que surge en momentos concretos de la vida, y del cual otras personas también pueden beneficiarse. En este sentido, la ejecución del autocuidado necesita de una acción intencionada, determinada por el conocimiento y la compilación de habilidades del individuo y se fundamenta en la premisa de que las personas están conscientes cuando requieren ayuda y, por lo tanto, son conscientes de las acciones concretas que requieren realizar. Aunque los individuos pueden seleccionar la no-acción, esto quiere decir, pueden disponer no iniciar una conducta de autocuidado cuando es requerida, por las más variadas razones que pudieran circunscribir la angustia, el recelo, o por tener otras prioridades.

\section{Época de pandemia}

El once de marzo de 2020 la OMS anunció el Coronavirus COVID-19 como pandemia. Ese momento histórico significó, significa y probablemente significará el comienzo de una transformación en los diferentes estilos de vida de la sociedad mundial. Esta epidemia, cuyo origen se le atribute a la ciudad China de Wuhan, provoca que más de 180 países la afronten con protocolos experimentales. Sin embargo, sus resultados aún resultan una incógnita.

Respiradores, tapabocas, jabón, solución antibacterial, cuarentena y distanciamiento social han sido las medidas sanitarias recomendadas por los especialistas con el propósito de frenar y desacelerar la escalada del virus. Urge el llamado al personal de salud y se apoya la proliferación de hospitales centinelas, de campaña y la dotación de equipos y medicinas para atender a la población infectada. Por otra parte, a nivel mundial se han sentido los efectos de la pandemia en los contextos económicos y sociales. Asimismo, la rápida propagación del virus reclama acciones inmediatas y si por una parte esto blinda a los Estados, esta situación conlleva transformaciones en la geopolítica mundial.

En el caso de Venezuela, han trascurrido cuatro meses desde el trece de marzo cuando se decretó el estado de alarma nacional y la cuarentena social y colectiva para detener la proliferación de la COVID-19. Este virus enclaustró a millones de venezolanos, iniciándose la primera fase del confinamiento el lunes dieciséis de marzo contemplando siete Estados, mientras que al siguiente día la orden se extendió a todo lo largo de la geografía nacional. Durante las primeras semanas las fronteras fueron cerradas, los vuelos nacionales e internacionales prohibidos y se 
restringió la circulación de vehículos entre los Estados. En el plano de la seguridad se instalaron alcabalas policiales y militares. Estas solo permitían el tránsito a quienes poseyeran salvoconductos, tal es el caso del personal de salud, empleados del sector de alimentos y medios de comunicación e información. Durante esos primeros días, prevalecieron la incertidumbre, la intranquilidad, el recelo, el aislamiento y el miedo al contagio, a quedar cesante o perder los negocios. No obstante, a la media radical del gobierno, esta fue asumida por los sectores productivos $y$, por ende, por los ciudadanos.

Las personas incorporaron a su rutina las medidas sanitarias, entre ellas el uso cotidiano del tapabocas, guantes, soluciones antibacteriales y el distanciamiento social. El gobierno informó a la ciudadanía que la referencia para abordar la crisis sería el modelo chino. Asimismo, se solicitó apoyo humanitario a la OMS y recibió colaboración de China, Rusia y de la Cruz Roja Internacional. Otra solicitud emanada del ejecutivo estuvo en solicitar el cese al bloqueo de los fondos venezolanos para utilizarlos en la lucha contra la COVID-19 y el levantamiento de las sanciones por parte de Estados Unidos, actos posteriormente negados.

En el plano social, el gobierno colocó una encuesta en la plataforma patria, ("mecanismo creado por el presidente Nicolás Maduro con el propósito de otorgar beneficios del sistema socialista directamente a la población" señaló Rodríguez, 2020:2), de allí los organismos pertinentes recopilaron información que les facilitó, por una parte, ejecutar visitas casa por casa para realizar despistajes de casos y por la otra; ir construyendo un mapa epidemiológico para ubicar los focos de contagio en el país. Otra acción generada por el gobierno fue la conformación de la Comisión Presidencial para la Prevención de la COVID-19, presidida por la vicepresidenta Delcy Rodríguez, quien, junto a otros miembros del gabinete ministerial, resultaron ser los voceros de los partes diarios. Sobre esto, Unión Radio (2020) reporta:

Los casos iniciales detectados estuvieron relacionados con personas que viajaron a Europa, en especial a aquellos países que fueron el epicentro de la pandemia en marzo como Italia y España. La región Capital (Miranda, Dtto Capital y La Guaira) junto a Aragua concentraron la mayoría de los diagnósticos. En marzo se conoció el primer foco de la pandemia, originado por una fiesta de reguetoneros en la isla de los Roques, archipiélago donde a sus habitantes se les practicaron pruebas rápidas. El 26 de marzo se informó del primer fallecido por el virus, un trabajador del estado Aragua que se contagió por un contacto con viajero de Panamá. Al día siguiente, el 27, falleció una mujer en Miranda y el 29 de marzo murió un taxista de Antimano... (párr. 1) 
Sobre la base de estos sucesos el gobierno inició sus partes oficiales y en ellos se comenzó a separarlos tipos de contagio, surge entonces la expresión "contagios comunitarios" en contradicción con los "contagios importados" siendo estos últimos los que se adquieren por tener contacto con alguna persona que ha regresado de un viaje internacional. Una mención de contagio colectivo merece recordarse con la detención de diecisiete personas que se encontraban en una fiesta al este de la ciudad capital, trasgrediendo la cuarentena, de las cuales dos resultaron conminadas.

Durante abril, el gobierno asumió la responsabilidad de recibir retornados por los puestos fronterizos con Colombia, se les practicaron pruebas rápidas y se dio la orden de resguardarlos, a modo de cuarentena, en los PASI en Táchira durante dos semanas. Se comenzó a decretar toque de queda en los municipios fronterizos con el propósito de controlar a los retornados de Colombia, Perú y Ecuador. Otra orden del presidente fue culminar el año escolar en educación a distancia, pese a las dificultades de conectividad y acceso a los medios de información y comunicación. Un sector importante del país también asumió el trabajo a distancia y adaptándose al teletrabajo.

En este sentido, el presidente Nicolás Maduro informó al país que el mayor foco de la pandemia estaba en la zona fronteriza con Colombia, fortaleciendo las medidas sanitarias y trasladando a los retornados a PASI en sus ciudades de origen. Posteriormente, se unió a esta alerta la frontera con Brasil debido al aumento de casos en el Estado de Roraima y Manaos y el surgimiento de casos en el estado Bolívar. No obstante, para abril se dio el primer ensayo de flexibilización de la cuarentena, donde se permitió salir en horarios alternos a niños y adultos mayores.

Luego, para mayo, el gobierno informó que se había logrado la contención y control de la pandemia, y aunado a esto, muchos de los casos de contagio se mantenían asintomáticos. No obstante, se renovó el decreto de alarma. Se realizaron nuevas pruebas de desescalada organizada bajo los protocolos sanitarios, sustentados en la reducción de horarios y normativas para el acceso a los establecimientos comerciales. Sin embargo, a mediados de mayo, las cifras de contagios se incrementaron y el gobierno apuntó al masivo retorno de connacionales (casos importados). como causa principal Pero esta situación no detuvo una nueva medida de flexibilización, que en un principio se denominó $5 \mathrm{X} 10$ y luego término en $7 \mathrm{X} 7$, es decir, siete días de labor y siete de cuarentena social y colectiva. Obsérvese el gráfico $\mathrm{N}{ }^{\circ} 4$ : 


\section{Esquema de $7 x 7$ en 3 Niveles.}

Wivel1 Guarentena Radical:

Acá solo trabajaran los siguientes:

Sector Alimentación/Sector Salud

En el Estado Apure los sectores fronterizos deben permanecer en Cuarentena

\section{[T] Flexibilización Parcial de sectores:}

Construcción/Bancos/Transporte/Ferreteria/Alimentos

Médico y odontológico/Peluquería y textil/Talleres

Reparaciones en casa y plomeria/Materia Prima/

Telecomunicaciones

\section{DTuel3 Flexibilización total de sectores:}

Todos los del nivel 2, agregando los siguientes sectores:

Ópticas/Autolavados/Reparaciones de Teléfonos y eléctronica

textil y calzado/Papelerías y librería/Heladería y cafetería

Lavandería y tintoreria/Ensambladoras equipos en general

Servicio encomiendas y envios/Registro y notaria/Gimnasios

Eventos deportivos sin público/Centros Clínicos Veterinarios

Centros Comerciales/Autocines

Gráfico. 4. Bertilio Pérez. Esquema de 7x7. En Solo Reportes. Adaptado por los investigadores

Durante junio y julio se continuó con el plan de flexibilización de los sectores de la economía, se incrementó el precio de la gasolina y la curva que representa el aumento en la frecuencia de los casos importados y casos comunitarios continuó elevándose. Esto ha ocasionado que tanto el gobierno como la oposición política venezolana en concordancia, con la Organización Panamericana de la Salud, acordaran buscar recursos que les permita enfrentar la pandemia. Hasta el momento de redacción de esta investigación no se ha presentado oficialmente una vacuna contra la COVID-19, también, se ignora cuándo se retomarán las rutinas, no obstante, todo parece indicar que se continuará viviendo una "nueva normalidad o normalidad relativa y vigilada".

\section{Metodología}

Esta es una investigación cualitativa, bajo el enfoque teórico-metodológico biográfico (Ferraroti, 2008, p. 29), y desde la perspectiva del relato de vida, entendida como una reflexión de lo social desde un relato personal. Tiene su base en la subjetividad y en la experiencia del individuo, no siendo necesariamente este individuo un ser especial, lo importante es que sea integrante de la comunidad que se estudia, en este caso, se indaga el complejo y heterogéneo imaginario social de los retornados al sector popular. El Carpintero de Petare en época de pandemia. En este sentido, se toma a Mallimaci y Giménez (2006) cuando señala: “...El relato de 
una vida debe verse como resultado acumulado de las múltiples redes de relaciones en los que, día a día, los grupos humanos entran, salen y se vinculan por diversas necesidades..." (p. 2). Por consecuencia, el relato de vida es una entrevista donde se intenta conocer lo social desde lo individual.

Esta investigación posee una sustentación par adigmática y en este caso preciso. Coincide con el paradigma hermenéutico interpretativo. Según Barrero, Bohórquez y Mejía (2011) se reconoce como:

...parte de reconocer la diferencia existente entre los fenómenos sociales y naturales, buscando la mayor complejidad y el carácter inacabado de los primeros, que están siempre acondicionados por la participación del hombre. Abarca un conjunto de corrientes humanísticos-interpretativas, cuyo interés fundamental va dirigido al significado de las acciones humanas y de la vida social... (p.106)

La finalidad de este paradigma es profundizar en el conocimiento y comprender la conducta de los individuos estudiados, en este caso los migrantes-retornados, lo cual se alcanza cuando se interpreta sus significados, actos y pensamientos. Para organizar la información mencionada es importante observar el siguiente cuadro $\mathrm{n}^{\circ} 3$ sobre la pentadimensión de los retornados en época de pandemia:

Cuadro 3. Pentadimensión de los retornados en época de pandemia

\begin{tabular}{|c|c|}
\hline Base & Retornados en época de pandemia \\
\hline Epistemológica & $\begin{array}{l}\text { El conocimiento se produce a partir de la interacción con } \\
\text { los participantes de la investigación en los procesos de }\end{array}$ \\
\hline $\begin{array}{l}\text { ¿Cómo se produce } \\
\text { él produce el } \\
\text { conocimiento } \\
\text { dialectico? }\end{array}$ & $\begin{array}{l}\text { socialización. A partir de una mirada epistemológica, donde } \\
\text { es factible confrontar el orden predominante y enfrentar la } \\
\text { lógica implantada que se soporta en las medidas sanitarias } \\
\text { para prevenir la COVID-19, y que deben observar los } \\
\text { migrantes-retornados a Venezuela, en nombre del bien } \\
\text { colectivo. }\end{array}$ \\
\hline Ontológica & $\begin{array}{l}\text { Compartida. Los retornados están conscientes en la } \\
\text { irregularidad conflictiva que existe entre un ser y su lugar de }\end{array}$ \\
\hline $\begin{array}{l}\text { ¿Cuál es la naturaleza } \\
\text { de la realidad? }\end{array}$ & $\begin{array}{l}\text { origen y otro ser que está en su no lugar. Por otra parte, la } \\
\text { pandemia, las políticas económicas y sociales, transforman } \\
\text { constantemente la realidad de los migrantes-retornados y } \\
\text { sirven de puente para el desplazamiento de las personas de } \\
\text { sus lugares "destino y/o tránsito" a sus lugares de origen. }\end{array}$ \\
\hline
\end{tabular}




\begin{tabular}{|c|c|}
\hline Base & Retornados en época de pandemia \\
\hline Axiológica. & $\begin{array}{l}\text { Valores compartidos y convividos. El retorno conforma una } \\
\text { base moralista controladora, como fundamento para todo ser }\end{array}$ \\
\hline $\begin{array}{l}\text { ¿Qué valores } \\
\text { son inherentes al } \\
\text { conocimiento que se } \\
\text { produce? }\end{array}$ & $\begin{array}{l}\text { humano que transite y regrese a su país. Este fundamento } \\
\text { moralista controlador será el agente que impondrá } \\
\text { mecanismos de autorregulación, entendido esto en los límites } \\
\text { y respeto a las diferentes normas y reglas que entran en } \\
\text { juego, desde el lugar de donde se parte hasta el lugar donde } \\
\text { se pretende llegar. }\end{array}$ \\
\hline Teleológica & $\begin{array}{l}\text { Se pretendió en el orden teleológico que tanto los migrantes- } \\
\text { retornados, las líderes comunitarias y los otros actores }\end{array}$ \\
\hline $\begin{array}{l}\text { ¿Cuál es la finalidad } \\
\text { del conocimiento } \\
\text { producido? }\end{array}$ & $\begin{array}{l}\text { sociales conozcan los sustentos legales y sociales para el } \\
\text { recibimiento, trato e inserción de estos connacionales en el } \\
\text { país y especialmente en sus comunidades durante esta época } \\
\text { de pandemia. }\end{array}$ \\
\hline Metodológica & $\begin{array}{l}\text { Se buscó una aproximación al punto de vista de las personas } \\
\text { implicadas, a través del método biográfico de sus relatos }\end{array}$ \\
\hline $\begin{array}{l}\text { ¿Cómo se } \\
\text { operacionaliza el } \\
\text { método para producir } \\
\text { conocimiento? }\end{array}$ & $\begin{array}{l}\text { de vida. Tras el esbozo de las experiencias del migrante- } \\
\text { retornado, se analizan diversas categorías referentes al } \\
\text { proceso migratorio en sus diferentes etapas: razones para } \\
\text { la emigración, adaptación, desarraigo hasta el retorno y los } \\
\text { conflictos de readaptación en tiempo de pandemia. }\end{array}$ \\
\hline
\end{tabular}

Nota. Cuadro elaborado por investigadores con reflexiones teóricas inspiradas en "Los derechos humanos de migrantes" por la Comisión Chilena de Derechos Humanos, 2000, La Paz-Bolivia.

\section{Los escenarios, las unidades de información y los participantes clave}

\section{Escenarios}

Con relación al escenario donde se desarrolla la siguiente indagación y en concordancia con su diseño, la temporalidad y donde se desarrollan las narraciones, se tomó al sector El Carpintero de Petare en el municipio "Antonio José de Sucre" en el Estado Miranda, Venezuela. Obsérvese la gráfica N. ${ }^{\circ}$ 5: 


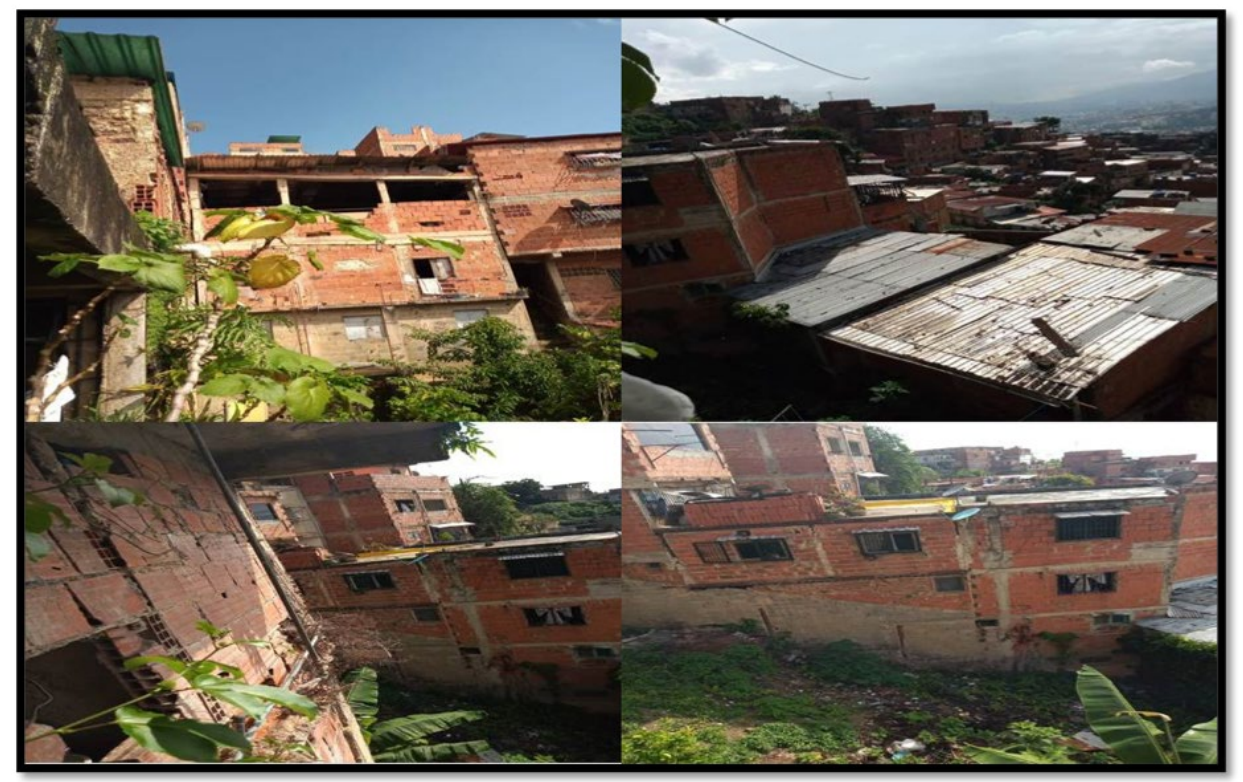

Gráfica 5. Sector El Carpintero de Petare.

Elaborada por los investigadores.

Este sector popular es uno de los más altos de Petare sur, estimándose que se ubica a 980 metros sobre el nivel del mar, su fundación data de los cincuenta del siglo pasado y cuenta con una población aproximada de 50000 habitantes, cuyas casas se aprecian muy cercanas las unas de las otras, situación riesgosa en esta época de pandemia. Sobre ello, se expone en El Clarín (2020):

“¡A retirarse a sus casas!”, ordenan con megáfonos militares y policías en Petare, la mayor favela de Venezuela, haciendo valer una cuarentena ante la propagación del nuevo coronavirus que personas como Gladys rompen para "guerrear" contra el hambre... Gladys es uno de los 400.000 habitantes de esta barriada del este caraqueño, un sinfín de viviendas de bloques y techos de zinc levantadas desordenadamente sobre montañas desde mediados de siglo pasado, donde los servicios de agua, gas doméstico y recolección de basura son precarios. Desciende por angostas escalinatas para "guerrear" en calles colmadas de buhoneros y multitudes de peatones desde la mañana hasta la noche. Pero ahora, en tiempos de pandemia, esa efervescencia se limita a cuatro horas por jornada... (p. 1)

En este orden, cabe aclarar que la parroquia de Petare con sus diferentes sectores populares, representan un contexto donde frecuentemente se incrementa el número de contagios por COVID-19. No obstante, y a pesar de las sanciones y 
especialmente en las mañanas, cuando sus calles están abarrotadas de personas que transitan principalmente en busca de alimentos. Es necesario señalar que durante nuestra observación por el sector El Carpintero los presentes no usaban adecuadamente el tapabocas. Incluso, un número significativo no lo llevaban consigo, tampoco respetaban el distanciamiento social, normas clave para impedir la transmisión del virus.

\section{Unidades de información y participantes clave}

Con respecto a las unidades de información, que generaron los insumos para la construcción del corpus de estudio, estas se conforman con los microrrelatos sociales, esbozados por los cinco participantes clave que hacen vida en el escenario de estudio. Son ellos un vecino retornado y su compañera de vida, un testigo de excepción, dos líderes comunitarias y los investigadores rol de observadores participantes, ver cuadro 4 :

Cuadro 4. Participantes clave

\begin{tabular}{l|l|l}
\hline Participantes & & Nomenclaturas \\
Retornado & A & $1 \mathrm{~A}$ \\
Compañera de vida del Retornado & $\mathrm{B}$ & $2 \mathrm{~B}$ \\
Testigo & $\mathrm{C}$ & $3 \mathrm{C}$ \\
Líderes comunitarias & $\mathrm{D}, \mathrm{E}$ & $4 \mathrm{D}, 5 \mathrm{E}$ \\
Observadores-participantes & & Investigadores \\
\hline
\end{tabular}

Nota. Cuadro elaborado a partir de la escogencia intencional de los participantes clave de la investigación por parte de los autores.

\section{Diseño de la investigación}

En el caso específico de la presente investigación, esta se ajusta al diseño narrativo, en el cual se compilaron datos sobre las experiencias de un conjunto de personas, que serán descritas y analizadas. Quienes resultaron de interés son los llamados retornados, así como otros individuos pertenecientes a su entorno. Para Creswell, interpretado por Salgado (2007):

...el diseño narrativo en diversas ocasiones es un esquema de investigación, pero también una forma de intervención, ya que al contar una historia ayuda a procesar cuestiones que no estaban claras. Se usa frecuentemente cuando el objetivo es evaluar una sucesión de acontecimientos... (p. 73). 
Los datos se consiguieron a través de la entrevista biográfica y de testimonios (así como de artículos de prensa, fotografías, entre otros). En esta ocasión, se hará referencia a unos relatos de vida. Estos nos permitirán analizar un episodio de la historia de vida de nuestros participantes clave, así como "...el ambiente (tiempo y lugar) en cual...sucedieron los hechos; las interacciones, la secuencia de eventos y los resultados..." (p.73).

Los investigadores reconstruyeron una cadena de sucesos (de forma cronológica, considerando de los primeros hechos a los últimos), consecuentemente, se narraron desde nuestra óptica y se procedió a describirlos (sobre el soporte de la evidencia disponible), asimismo, se identificaron categorías y temas emergentes en los datos narrativos (que proceden de los relatos contados por los participantes clave, los documentos, materiales y la propia narración de los investigadores). Este estudio narrativo se considera de tópico, ya que está enfocado en una temática, suceso o fenómeno: el imaginario de los retornados en época de pandemia.

\section{Técnica para la recolección de información}

\section{Análisis de contenido cualitativo}

El análisis de contenido cualitativo es una técnica dirigida a descubrir el significado de un mensaje, sea este un discurso, una historia de vida, un relato de vida, un artículo de revista etc. Especialmente, se trata de una técnica que se sustenta en la clasificación o codificación de los diversos elementos de un comunicado en categorías con el propósito de hacer emerger de forma congruente su sentido. Entrevista biográfica

Hace referencia a una narración y/o un microrrelato social en primera persona, ya que lo que se pretende recuperar son las experiencias de esa persona. No se pretende que sea un proceso saturado y/o exhaustivo, sin embargo, se espera pueda tener como epicentro un momento o aspecto de la vida. En este sentido, Ferrarotti (2008) acota:

... Toda entrevista biográfica es una interacción social compleja, un sistema de roles, de expectativas, de suposiciones, de normas y de valores implícitos, con frecuencia también de sanciones. Toda entrevista biográfica esconde tensiones, conflictos y jerarquías de poder, apela al carisma y al poder social de las instituciones científicas con respecto a las clases subalternas y evoca sus reacciones espontaneas de defensa. No se cuenta la propia vida y las propias vivencias a un grabador; se las cuenta a un individuo... (pp. 33-34) 
Tampoco se cree que la entrevista pueda contar con criterios de totalidad. Se piensa que todo individuo cuenta con un componente selectivo que a partir del presente lo lleva a recordar o dejar de lado determinados hechos, y este proceso debe ser respetado por los investigadores.

Para la presente investigación se empleó una entrevista biográfica semiestructurada, con el propósito de obtener aproximaciones teóricas que nos permitieron caracterizar cuál es el imaginario social que emerge en torno a los retornados a Petare en época de pandemia. Con el propósito de diligenciar este proceso se procedió a consensuar entre los investigadores un guion de entrevista. Este mismo fue empleado durante la entrevista con los participantes clave. Los planteamientos se emplazaron hacia la descripción del contexto, su autopercepción con relación a los calificativos a los cuales son objeto los retornados, la concepción del cuidado y autocuidado en época de pandemia y los aprendizajes generados por la experiencia del viaje. Las entrevistas fueron compiladas con el propósito de recolectar los sucesos y acontecimientos dignos de ser investigados y, posteriormente, ser cotejados con el supuesto de la investigación. En el siguiente cuadro (5) se resume la sistematización de las narraciones obtenidas en las entrevistas:

Cuadro 5. Análisis de la entrevista al retornado. (Una mirada parcial al ejercicio)

\begin{tabular}{lll}
\hline Planteamientos & \multicolumn{1}{c}{ Relato de vida } & Temas (emergentes) \\
\hline ¿Cómo llegaste & 1A. Le voy a contar, yo me fui el 11 de & Migración \\
a Venezuela & marzo para Colombia específicamente para & \\
en época de & el departamento de Bolívar en Cartagena, en & \\
pandemia? & un pueblo que se llama La Ciénega, al cual & \\
& hay que llegar por el río en lancha, fui para & \\
& el velorio de mi papá, no me costó salir de & Cuarentena \\
& Venezuela por la frontera con Maicao, ni & Cuidado \\
& $\begin{array}{l}\text { llegar a la casa, pero cuando llegué ya habían } \\
\text { enterrado a mi papá y enseguida decretaron la }\end{array}$ & Pandemia \\
& cuarententena en Venezuela y me tocó quedarme & Déficit de \\
& seis meses allá, trabajando la agricultura y la & autocuidado \\
& ganadería, y cuidando a mi mamá, por allá & \\
& no hay nada de pandemia, eso es en Bogotá, & \\
& pero también declararon cuarentena, la policía & \\
& colombiana devolvía las lanchas con pasajeros & \\
& del río, sino yo me hubiese venido antes... & \\
\hline
\end{tabular}




\begin{tabular}{|c|c|c|}
\hline Planteamientos & Relato de vida & Temas (emergentes) \\
\hline $\begin{array}{l}\text { ¿Y cómo estuvo } \\
\text { el viaje de } \\
\text { retorno, te costó } \\
\text { mucho llegar a } \\
\text { tu casa? }\end{array}$ & $\begin{array}{l}\text { 1A. El viaje estuvo bien, yo no me quité el } \\
\text { tapabocas, los guantes y me cuidé mucho. Yo } \\
\text { sé que B2 [su pareja] me había explicado que } \\
\text { debía guardar cuarentena...por el camino no } \\
\text { vi nada extraño y cuando llegué a la frontera, } \\
\text { allí sí había mucha gente, pero logré pasar } \\
\text { y bueno, me arreglé con una autoridad y el } \\
\text { mando para Barquisimeto, me dio miedo } \\
\text { quedarme en esos refugios en Maracaibo, } \\
\text { había muchas mujeres con niños y ellas eran } \\
\text { la prioridad, un guardia me dijo, si tú no estás } \\
\text { contagiado pues con toda esta gente te vas a } \\
\text { contagiar... }\end{array}$ & $\begin{array}{l}\text { Retorno } \\
\text { Autocuidado } \\
\text { Cuarentena } \\
\text { Retornados } \\
\text { Corrupción } \\
\text { Miedo } \\
\text { Déficit de } \\
\text { autocuidado }\end{array}$ \\
\hline $\begin{array}{l}\text { ¿Entonces } \\
\text { te viniste de } \\
\text { trochero? }\end{array}$ & $\begin{array}{l}\text { Mire yo no soy ni trochero ni bioterrorista, yo } \\
\text { me vine a Venezuela pagando mi pasaje, en } \\
\text { Colombia no hay problemas de movilización, } \\
\text { y en Venezuela me movilicé pagando por } \\
\text { tramos, yo me paraba en los puestos de la } \\
\text { autoridad y allí lograba ubicarme, así también, } \\
\text { me vine de Barquisimeto a Petare donde un } \\
\text { señor me dejó en la autopista...yo no caminé } \\
\text { por trocha, yo llegué por carretera, no pasé } \\
\text { por trochas y estoy sano, luego me vine por } \\
\text { autopistas... }\end{array}$ & $\begin{array}{l}\text { Trochero } \\
\text { Bioterrorismo } \\
\text { Tochas } \\
\text { Salud }\end{array}$ \\
\hline $\begin{array}{l}\text { ¿Cómo lo } \\
\text { recibieron en } \\
\text { su casa y la } \\
\text { comunidad? }\end{array}$ & $\begin{array}{l}\text { A la casa, llegué un sábado y el lunes me fui } \\
\text { a trabajar, pero allá me dijeron que no podía } \\
\text { trabajar, que tenía que hacer cuarentena y } \\
\text { hacerme la prueba...y yo fui a Pérez de León } \\
\text { y no me hicieron la prueba, fui a un CDI y la } \\
\text { doctora me dijo que tenía que encerrarme por } \\
\text { quince días en la casa con mi señora y que } \\
\text { no se nos podían acercar ni los niños ni las } \\
\text { personas mayores y así hicimos...pero no sé } \\
\text { cómo se enteraron las mujeres del Consejo } \\
\text { Comunal y armaron un escándalo, una } \\
\text { gritaba en la calle pidiendo que me llevaran } \\
\text { a un refugio aterrada y luego vino otra que } \\
\text { habló con B2 y dijo que traería a los médicos } \\
\text { cubanos para que nos hicieran la prueba y que } \\
\text { no saliéramos de la casa y así lo hicimos... }\end{array}$ & $\begin{array}{l}\text { Cuidado laboral } \\
\text { Pruebas PCR } \\
\text { Cuarentena } \\
\text { Cuidado familiar } \\
\text { Cuidado comunitario } \\
\text { Refugio } \\
\text { Cuidado y } \\
\text { autocuidado } \\
\text { comunitario } \\
\text { Cuarentena }\end{array}$ \\
\hline
\end{tabular}




\begin{tabular}{|c|c|c|}
\hline Planteamientos & Relato de vida & Temas (emergentes) \\
\hline $\begin{array}{l}\text { ¿Qué aprendiste } \\
\text { de esta } \\
\text { experiencia? }\end{array}$ & $\begin{array}{l}\text { Yo me fui el año pasado por seis meses a } \\
\text { trabajar en Bogotá y me fue mal. No me } \\
\text { acostumbré a ese frio y a estar lejos de mi } \\
\text { familia, yo he vivido más tiempo aquí que } \\
\text { en Colombia y ahora el viaje no fue igual, } \\
\text { yo venía asustado y con miedo de no llegar, } \\
\text { nunca pensé vivir esto y ver tanto miedo en la } \\
\text { gente. Las personas pasaban corriendo por el } \\
\text { frente de la casa y comentaban que yo había } \\
\text { traído el virus al barrio... }\end{array}$ & $\begin{array}{l}\text { Migrante reincidente } \\
\text { Necesidad familiar } \\
\text { Sensibilización en } \\
\text { salud ambiental } \\
\text { Temor al COVID-19 } \\
\text { Fuente de contagio. }\end{array}$ \\
\hline
\end{tabular}

Nota. Cuadro elaborado a partir de una entrevista cualitativa diseñada y aplicada a los participantes claves por parte de los investigadores.

Cuadro 6. Análisis de la entrevista a la compañera del retornado. (Una mirada parcial al ejercicio)

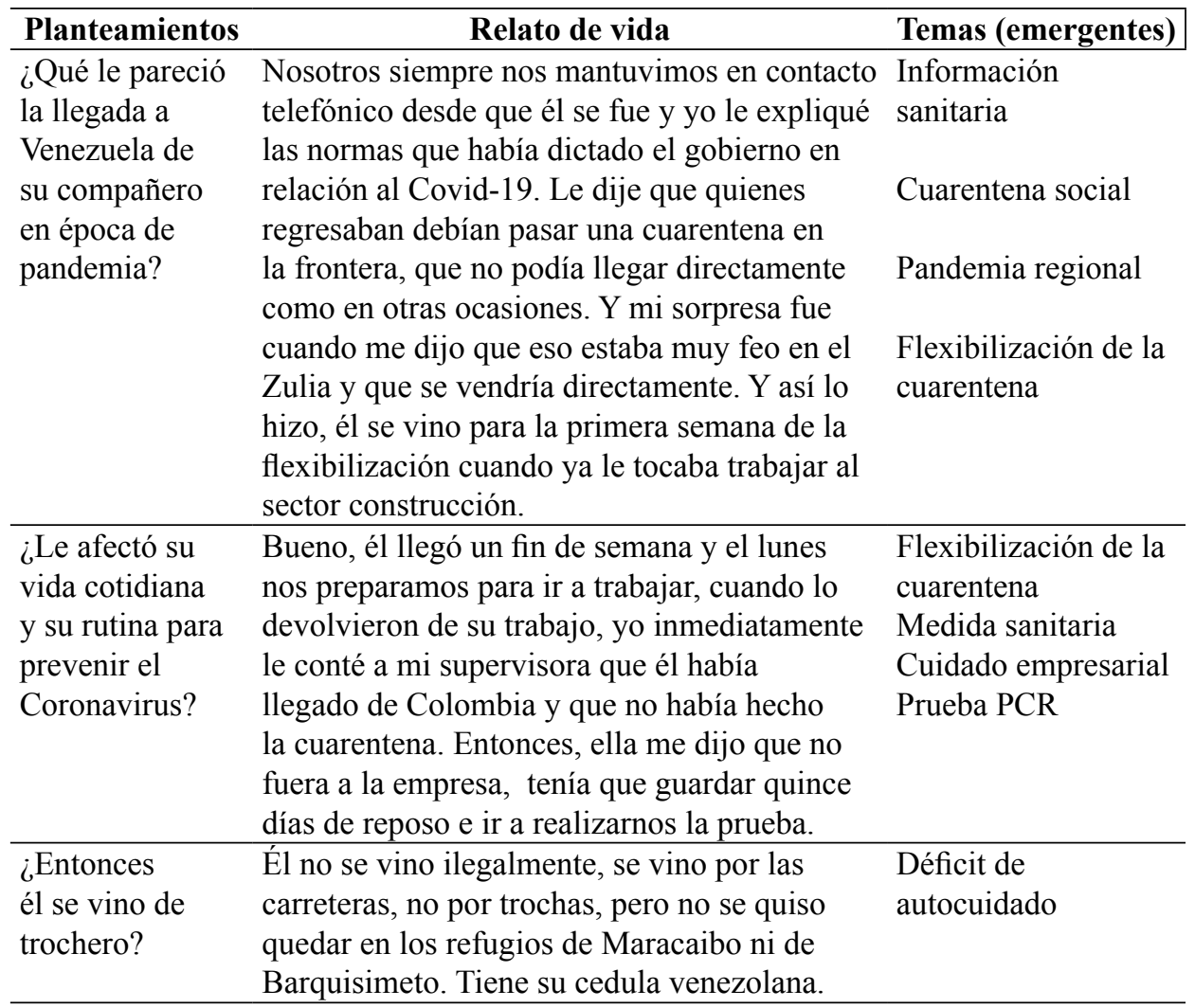




\begin{tabular}{|c|c|c|}
\hline Planteamientos & Relato de vida & Temas (emergentes) \\
\hline $\begin{array}{l}\text { ¿Cómo recibió } \\
\text { la comunidad } \\
\text { la llegada de su } \\
\text { compañero? }\end{array}$ & $\begin{array}{l}\text { Horrible, mi madre no quiso que la } \\
\text { visitáramos y se asustó mucho. Las integrantes } \\
\text { del consejo comunal se enteraron, y una } \\
\text { gritaba a nuestra casa que él era un trochero, } \\
\text { que había traído el virus al barrio, que no } \\
\text { podíamos salir ni comprar y se lo informó al } \\
\text { resto de los vecinos que pasaban con miedo } \\
\text { por la puerta de la casa. Tuvimos que mandar } \\
\text { a hacer las compras con mi hija que vive en } \\
\text { otra casa, así hicimos para comprar el gas, } \\
\text { nos prohibieron salir de casa y nosotros lo } \\
\text { acatamos. Luego vino otra integrante del } \\
\text { consejo comunal y nos informó que vendrían } \\
\text { los médicos cubanos a revisarnos y que no } \\
\text { podíamos salir, pero nunca vinieron, a los } \\
\text { quince días comenzamos a salir, estamos } \\
\text { sanos. }\end{array}$ & $\begin{array}{l}\text { Temor al COVID-19 } \\
\text { Cuidado y } \\
\text { autocuidado } \\
\text { comunitario } \\
\text { Autocuidado } \\
\text { Cuarentena } \\
\text { comunitaria } \\
\text { Déficit de } \\
\text { autocuidado }\end{array}$ \\
\hline $\begin{array}{l}\text { ¿Qué aprendió } \\
\text { de esta } \\
\text { experiencia? }\end{array}$ & $\begin{array}{l}\text { Me asusta mucho el virus y estaba muy } \\
\text { preocupada pensando en las consecuencias de } \\
\text { la enfermedad y de la reacción a la gente. De } \\
\text { broma no nos lincharon. Ya estoy asistiendo } \\
\text { al trabajo de nuevo, guardo todas las medidas } \\
\text { con el tapabocas, el gel y lavado de manos y } \\
\text { solo hago las salidas necesarias. }\end{array}$ & $\begin{array}{l}\text { Sensibilización en } \\
\text { salud ambiental } \\
\text { Medidas sanitarias }\end{array}$ \\
\hline
\end{tabular}

Nota. Cuadro elaborado a partir de una entrevista cualitativa diseñada y aplicadas al participante clave por parte de los investigadores.

\section{Procedimientos}

- Mostrar las acciones con detalles, con una mirada etnográfica y como soporte para interpretar.

- Ubicar los códigos de esos acontecimientos.

- Interpretarlos en relación con la teoría. 
Cuadro 7. Unidad de análisis: aproximación conceptual

\begin{tabular}{ll}
\hline \multicolumn{1}{c}{ Temas emergentes (reagrupados) } & \multicolumn{1}{c}{ Categorías } \\
\hline Migración & El retornado a Venezuela \\
Cuarentena & \\
Cuidado & \\
Pandemia & \\
Flexibilización de la cuarentena & \\
Retornados & La Inteligencia vecinal detecta al \\
Migrante reincidente & trochero \\
\hline Autocuidado & \\
Miedo & \\
Medida sanitaria & Biopeligroso \\
Cuidado empresarial & \\
Prueba PCR & \\
\hline Trochero & \\
Bioterrorismo & \\
Tochas & \\
Salud & \\
Temor al COVIT-19 & \\
Pruebas PCR & La quedo en casa \\
Autocuidado & pandemia \\
Déficit de autocuidado & \\
\hline Fuente de contagio & \\
Sensibilización en salud ambiental & \\
Medidas sanitarias & \\
Información sanitaria & \\
Refugio & \\
\hline Cuidado y autocuidado comunitario & \\
Cuidado laboral & \\
Cuidado familiar & \\
Cuarentena social & \\
Cuidado comunitario & \\
Cuarentena comunitaria & \\
\hline & \\
\hline
\end{tabular}

Nota. Cuadro elaborado a partir del análisis de categorización aplicado por los investigadores a las entrevistas aplicadas a los participantes clave.

\section{Triangulación}

La triangulación es una técnica, tal como lo señala Estrada (2020). En ella se cruzan tres o más tópicos u otros observadores o diferentes repositorios con datos. Estos pueden ser cualitativos/cuantitativos. Deben ser, por lo menos, tres, ya que resulta en un aval de la fiabilidad e igualmente es válido para minimizar las réplicas y disminuir la dubitación por el uso de un solo método. 
Como método de investigación, la triangulación es una técnica que permite validar los hallazgos obtenidos durante el trabajo de campo. Su soporte, según Vallejo (2009), radica en que cuando un supuesto supera la comparación de diferentes metodologías posee entonces un alto grado de validez, más que si procediera de una sola de ellas.

\section{Análisis, interpretación y discusión de los hallazgos}

\section{El retornado a Venezuela}

El retorno a Venezuela es un proceso continuo, según informe de la Oficina de Asuntos Humanitarios de las Naciones Unidas (OSHA-2020). En este sentido, indica este documento que entre abril y julio de 2020 han retornado aproximadamente 72.517 personas por las fronteras terrestres, especialmente por el estado Táchira, en contradicción a migración Colombia. Allí se aseguró que son más de 90000 personas las retornadas. En estos sectores fronterizos las autoridades fijaron los PASI. En ellos, las personas que regresan deben permanecer por un lapso que va de dos semanas a veintiún días antes de poder continuar el viaje a su destino final. No obstante, también estos organismos coinciden en asegurar, que muchos otros venezolanos han regresado de forma irregular por otras áreas de la frontera, los cuales han generado según OCHA (2020):

...un cambio en la tendencia del tipo de contagios desde el 6 de julio, reportándose mayor incidencia de casos por transmisión comunitaria que de casos importados confirmados en las personas retornadas. Al 28 de julio, el número de casos de transmisión comunitaria representaba el 67 por ciento del total de casos (11.121) frente al 33 por ciento de casos importados (5.450) ... (p. 2).

En relación con esto último, un porcentaje de los retornados llegan hasta la frontera en autobuses financiados por el gobierno colombiano, otros han llegado caminando, huyen del ahogo de la economía informal, de no poder pagar los alquileres de sus viviendas debido a las medidas de aislamiento y cuarentena decretadas en los países que le habían dado acogida. En fin, son muchas las razones para regresar, sin embargo, lo cierto, en lo que todos coinciden, es que deben esperar los lunes, miércoles y viernes para que se les autorice a los retornados el ingreso al país, todo ello con el propósito de acentuar las medidas sanitarias de prevención, control del flujo migratorio y los brotes de COVID-19 durante la pandemia.

\section{La inteligencia vecinal detecta al trochero}

Los participantes D4 y E4 son miembros de la comuna en sector El Carpintero de Petare, zona rodeada de barrios afectados por el coronavirus. Desde que inició la 
pandemia, con apoyo de las autoridades municipales, han promovido campañas de concientización entre los vecinos, enseñando cuáles son las principales normas sanitarias que se deben cumplir, tales como el lavado de manos, uso del tapabocas, la importancia del distanciamiento social y el acatamiento de la cuarentena.

No obstante, después de varios meses de emergencia sanitaria por la COVID-19, se logró observar en el trabajo de campo y se corroboró en una entrevista exprés que las personas no usan correctamente el tapabocas. Esto se ha convertido, en muchos casos, en un accesorio que complementa el vestuario y que se usa cuando se va a Petare, capital del municipio, se suscitan reuniones sociales y aglomeraciones de adultos y niños en las calles. Ellas manifiestan que sienten una seria preocupación por los adultos mayores de la comunidad y que esperan que los vecinos asuman su corresponsabilidad y se concienticen sobre la situación y que esas es una de las razones por la cual sintieron tanta alarma ante la llegada de $1^{\mathrm{a}}$ al sector sin haber guardado la debida cuarentena y haberse realizado la prueba que determina si estaba contaminado con el virus o no. En este sentido, Navas (2020) quien entrevista al alcalde José Vicente Rangel Avalos destaca:

...desde la Sala Situacional Municipal para la Atención y Prevención del covid-19, hasta el pasado 30 de julio, en toda la jurisdicción se habían reportado más de 400 casos, siendo la parroquia Petare, la que continua concentrando la mayor cantidad de personas infectadas...indicó que en los sectores La Cruz, parte alta y baja, y Fila Maestra, del barrio Unión, se detectaron 42 personas infectadas, lo que convierte a este sector en uno de los focos más importantes del municipio...el segundo foco de importancia se localiza en las zonas 5 y 6 del barrio José Félix Ribas, en donde se detectaron 25 casos positivos, seguido por el barrio 12 de octubre en donde se reportaron 16 casos y el barrio La Agricultura con 12 casos positivos de covid-19... (p. 1)

Estos casos son referidos a los hospitales centinelas del municipio. En los sectores donde han ocurrido los repuntes, de manera coincidente son aquellos donde proliferaron las reuniones en las calles, allí hubo mayor consumo de licor y evidentemente se han ignorado todas las medidas sanitarias y de bioseguridad. Las mujeres líderes comunitarias junto a otros vecinos se han preocupado porque esto no ocurra en su comunidad y que se conserve la calidad da vida, a través de la conformación de brigadas de prevención y del acompañamiento a los grupos y médicos que realizan la visita casa por casa para realizar el despistaje.

Y un día recibimos una llamada de un vecino informándonos sobre la llegada de 1A. Este orden conversamos con $3 \mathrm{C}$, quien nos comentó que él había reportado la llegada de 1A, que él se ha cuidado mucho y sintió que el retornado podía romper 
la cuarentena al haber llegado a través de las trochas... "[1A] ingreso a Venezuela por las trochas, sin cumplir con los protocolos sanitarios, llego a su casa y nos puede contaminar a todo"... Finalmente, resultó que 1A no estaba contaminado de coronavirus, sin embargo, en este caso las mujeres líderes comunitarias lograron seguir la ruta de los contactos que tuvo el vecino, en atención a las instrucciones del CEOFANB citado por Marra (2020) cuando señala... "Un trochero o una trochera infectada es un bioterrorista en tu sector, que puede acabar con tu vida y la de tu familia...pide que se revele la dirección o cualquier otro dato que sirva para localizar al trochero..." (p. 1), a través de este mensaje el organismo oficial pide a los venezolanos que informen, sobre otros connacionales que regresan al país por vías irregulares, en las fronteras de Brasil y Colombia, bajo la premisa de evitar la propagación del virus COVID-19.

Finalmente, las mujeres líderes comunitarias piensan que 1A logró ser consciente del daño que pudo haberle causado a su familia y, por ende, a su comunidad. No obstante, durante la cuarentena comunitaria impuesta a 1A y 2B se les realizó seguimiento en relación a si presentaban síntomas y se mantuvieron alertas por si debían ser llevados a un centro centinela.

\section{Biopeligroso}

Durante esta época de pandemia ha proliferado, en el lenguaje oficial y sea replicado en el coloquial, el uso de categorías delictivas para renombrar a quienes utilizan los pasos ilegales en la frontera (trochas) para ingresar a Venezuela, en palabras de Delgado (citado por Soto, 2020) se considera:

... una persona que ingrese sin cumplir los protocolos de salud, va a ser acusada de bioterrorismo...nosotros no debemos tener ninguna contemplación con este tipo de personas que cometen este acto que es delictivo y que es un intento de homicidio contra la colectividad... (p. 1)

No obstante, para las organizaciones de derechos humanos estas conjeturas solo estigmatizan a los migrantes que por diversas razones, pero especialmente por la crisis económica-financiera ocasionada por el COVID-19, han tomado la decisión de retornar a Venezuela por vía terrestre, y puntualmente por caminos irregulares o trochas ante el cierre de las fronteras, sin embargo, son seres humanos en vulnerabilidad, no bioterroristas. Sobre este término la INTERPOL (2019) indica:

El bioterrorismo consiste en la liberación intencionada de virus, bacterias, toxinas u otros patógenos con el fin de causar enfermedades a personas, animales o plantas, 0 de provocar su muerte... el termino bioterrorismo hace referencia a la diseminación 
intencionada de agentes biológicos o toxinas para hacer daño y causar la muerte a civiles, animales o plantas con la intención de intimidar o coaccionar a un gobierno o a la población civil a favor de objetivos políticos o sociales... (p. 1)

Debido a esto, para considerar a un ciudadano como bioterrorista, este debe poder controlar el virus, manifestar la intención de diseminarlo (esto es lo que califica el delito); y acometer acciones para alcanzar metas políticas, sociales o económicas. En el caso de los retornados son solo personas que han desatendido el cuidado y el autocuidado y que, no obstante, son tratados como infractores, cuyos castigos pudieran acarrearle sanciones morales y hasta penales según sea el caso. Sobre el uso desproporcionado del término bioterrorista y los efectos controversiales de su aplicación cabe citar los trinos (tuit) del sacerdote jesuita Numa Molina (2020):

Todo el pueblo debe convertirse en un vigilante de su propio vecindario. La bioseguridad es tarea de todas y todos. Denuncia los trocheros sin miedo, es por tu bien...un \#trocheroinfectado es un bioterrorista que te puede quitar la vida a ti y a tus seres más queridos. Entren por los pases autorizados, bienvenidos a su patria pero sométanse a la cuarentena, no vengan a infectar a los venezolanos...está bien, no son bioterroristas, pero que quede bien claro que en el vecindario cuando se enteran que alguien llega del exterior por los caminos verdes la gente entra en pánico y tienen razón. He visto personas aterrorizadas...procura que tu regreso a tu lugar de origen sea una fiesta y no una tragedia, una zozobra para ti y los tuyos. Entra por los controles de inmigración, es por tu bien hermano, hermana...vamos a llamarlo biopeligroso, peligro biológico, presunto infectado, etc. de lo que sí quiero que quedes muy claro es que entrar en este momento al país por las trochas representa un grave peligro para ti y para la comunidad... (párr. 1)

Tal como lo señala la guía de la Organización Panamericana de la Salud (OPS) y la Organización Mundial de la Salud (OMS), la estigmatización social, tal como lo reseña también Marra (2020), es la vinculación negativa de un individuo (o un grupo) que posee determinadas características de una patología, En este manifiesto (OPS-OMS) se indica que el inadecuado manejo de la pandemia de COVID-19 podría haber generado “... estigmatización social y comportamientos discriminatorias en contra de personas de diferentes orígenes étnicos, o de cualquiera que se estime que ha estado en contacto con el coronavirus" (p.2). En el caso venezolano se ha vuelto una constante asociar, al aumento de casos positivos en contraprestación al retorno de connacionales, especialmente cuando se aprecia la distinción entre casos importados y casos por trasmisión comunitaria. 


\section{Salud ambiental en clave a la pandemia}

Estamos en un país cuyo sistema de salud reciente la crisis económica que lo embate desde hace algunos años. Cuando se implementó el decreto de cuarentena, los habitantes de las diferentes comunidades comenzaron a acatar las medidas sanitarias necesarias para prevenir la enfermedad. No obstante, a las carencias que ocupan a cada sector, tal es el caso de El Carpintero de Petare. Allí, los vecinos luchan por la falta de agua potable, de gas doméstico y otros insumos.

Sin embargo, con el paso de las semanas, muchas de estas personas relajaron las medidas de bioseguridad indispensables para prevenir el virus, en algunos casos, la razón esgrime en la necesidad de proveerse del sustento diario y en otros porque han dejado de creer en las consecuencias negativas del COVID-19, llegando al punto de organizar celebraciones y encuentros que en algunos casos han resultado focos de la enfermedad, sobre esto se destaca en el portal Banca y Negocios (2020):

El fin de semana la Policía Nacional Bolivariana suspendió 92 fiestas en el Área Metropolitana de Caracas para prevenir la propagación del covid-19...[se] instó al pueblo a cumplir las medidas de bioseguridad...Durante la supervisión el plan de flexibilización de la cuarentena en Petare, municipio Sucre, recordó que las fiestas han sido una de las principales fuentes de contagio... (párr. 1).

Ante esta situación de descuido, las autoridades competentes tales como la Guardia Nacional Bolivariana (GNB) o la Policía Nacional Bolivariana (PNB) entre otros cuerpos de seguridad accionan medidas coercitivas que van desde la detención provisional, el ejercicio físico, el trabajo comunitario, la asistencia a aulas de sensibilización ambiental y otras medidas que pudieran resultar abusivas o violatorias a los derechos humanos. Todo amparado en prevención a la proliferación del coronavirus. En este orden Marra (2020) acota:

Un testigo contó...que los funcionarios, con armas largas, lo mantuvieron en una unidad junto con 10 personas más, por caminar por las calles sin el tapabocas... [expreso el funcionario] Se pueden bajar todos con una condición: si los llego a ver por la zona en un minuto van presos...estuvieron aproximadamente una hora dentro de una unidad de la guardia, conocida como jaula...en ese tiempo los funcionarios se burlaron de ellos y los amedrentaron por no cumplir con las medidas... los detenidos tampoco guardaron el metro de distancia... (párr.1)

Estas prácticas se mantienen, y no es extraño observar videos y escuchar relatos sobre individuos amparados en credenciales que golpean o amedrentan a los vecinos de una determinada comunidad por estar fuera de sus casas, no usar tapabocas 
o por estar en reuniones deportivas o sociales en tiempos de pandemia y bajo cuarentena estricta.

\section{Me quedo en casa}

Sobre la base de lo que se ha venido planteando, se recalca la responsabilidad de los infractores ante un posible contagio, y en el mejor de los casos se les indica a los retenidos, la necesidad de asistir al centro de salud más cercano al detectar los síntomas de la enfermedad para que le realicen el protocolo de despistaje y de resultar positivo puedan ser recluidos y atendidos según sean sus antecedentes de salud. No obstante, muchos de los espacios acondicionados para la atención carecen de los insumos adecuados y el personal de salud ha resultado contaminado. Sin embargo, de resultar positivo en COVID-19, el aislamiento es imprescindible, pero sin que el paciente rompa sus canales de comunicación con los familiares. Se respetan sus derechos humanos, en este sentido, la organización Comadres Purpuras (2020) relata la vivencia Rodríguez:

...Richard Rodríguez director de Radiomanía en Carúpano, Edo Sucre, que junto a su esposa los llevaron a un local en condiciones deplorables y que además por hacer dicha denuncia, le dieron mal trato y que lo trasladaron por castigo a una habitación anexa a una morgue sin la ventilación adecuada... (párr. 1)

En este sentido, el establecimiento de este tipo de aislamiento en determinados sectores de la ciudad no debe involucrar la relajación de los cuidados ni el abuso de poder. Todo lo contrario, debe tener como norte mejorar las condiciones para que las personas que atraviesan esta etapa la superen con el menor riesgo y, por ende, el menor trauma. En relación con esto, se escogió otro relato de vida de las Comadres Purpuras (párr.3):

En mi caso soy madre soltera, cabeza de familia y sostengo a mi padre de 75 años y mi hija. Me negué comentarles a mis vecinos que me sentía mal, temía que me sacaran de mi hogar y me llevaran a quién sabe dónde, y si yo no produzco, literalmente mi familia no come. Afortunadamente, no tuve ni fiebre, ni perdí el olfato ni el gusto y mucho menos tuve dificultades respiratorias, quizá contraje cualquier virus que está en el ambiente y que por las lluvias siempre aparecen. Me mantuve en contacto con personas que podían articular con médicos por si acaso ameritaba una atención de ese tipo, como ya dije afortunadamente fueron 4 días de fuertes síntomas, mucho reposo y tomé pastillas para los dolores. Finamente me siento mejor, continúo con las medidas de protección en casa hacia mi familia, las que todos sabemos: vaso, plato y cubiertos solo para mi uso, constante higiene de las manos, cuerpo, limpieza del hogar de manera extrema y que nadie entre para mi 
cuarto. Hoy puedo decir que lamentablemente tengo miedo a enfermarme porque quien debería cuidarnos y garantizar la efectiva atención a nuestra salud: el Estado, más bien, nos agrede... (párr.1)

Como puede evidenciarse del relato, haber estado enferma y con temor a resultar contagiada de COVID-19 llevaron a la informante a dialogar con otras personas que habían superado el virus y que resolvieron hacer la cuarentena en sus casas, resguardadas en las medidas sanitarias. Es interesante resaltar que existe un grupo de personas que prefieren ocultar su enfermedad y plantearse "yo me quedo en casa", aludiendo que son jefes o jefas de hogar. Estas personas no tienen con quien dejar a sus hijos o adultos mayores y, por ende, tampoco pueden estar incomunicadas. Ante el cuestionamiento sobre el principio de corresponsabilidad, la informante admite sus dudas, no obstante, alega que ante la escasa garantía a una atención ajustada por parte de los organismos competentes, prefiere la opción de permanecer en casa, siempre y cuando sus condiciones de salud no se agraven.

\section{Consideraciones finales}

Las políticas públicas de prevención no pueden plantearse bajo condiciones que estigmaticen y produzcan temor y recelo en la colectividad. Esto no puede considerarse una forma productiva de controlar los contagios de COVID-19, en este marco:

Es necesario que el Estado venezolano disminuya toda práctica que coloque al retornado en una situación de mayor vulnerabilidad. Especialmente, al imputarles su responsabilidad en el aumento de casos confirmados por COVID-19. Si bien, para garantizar la seguridad de los ciudadanos es necesario cumplir con el aislamiento social, esto de ninguna manera puede ser empleado para profundizar la persecución de los retornados, por el contrario, debe avalar que dicho aislamiento sea en entornos preparados para tal fin, que garanticen sus derechos humanos y la no discriminación.

Se debe ofrecer información clara y precisa sobre la COVID-19, donde se recalque la importancia del cuidado y autocuidado, se explique la importancia de aplicar el principio de corresponsabilidad y se respete el derecho a la vida. La pandemia por COVID-19 no puede utilizarse como una excusa para naturalizar los tratos vejatorios y excluyentes hacia los afectados y su entorno familiar necesario crear mecanismos que contribuyan a elaborar medidas para la reinserción laboral de los retornados con salarios dignos que les permita su sostén y el de su entorno familiar, para así poder afrontar la vida cotidiana en tiempos de pandemia. 
Los retornados deben ser considerados para recibir formación en las aulas de sensibilización contra la pandemia y sus experiencias deben ser socializadas con el mayor respeto y bajo las más estrictas medidas de bioseguridad. Los retornados deben ser objeto de las pruebas para detectar la COVID-19 y deben recibir acompañamiento sanitario que garantice su salud, la de su familia y su comunidad, todo esto con el propósito de generar un cerco sanitario de ser necesario. El gobierno venezolano debe comprometerse a crear un plan estratégico que asegure y garantice los derechos humanos de los migrantes, así como del resto de la población donde se certifique el acceso a la atención médica de calidad, medicinas, alimentos, servicios públicos básicos (electricidad, agua potable, educación), es decir, todo aquello que pueda garantizar calidad de vida.

\section{Referencias}

ACNUR (7 de junio de 2019). Refugiados y migrantes de Venezuela superan los cuatro millones: ACNUR y OIM. [Artículo en línea]. https://www.acnur.org/noticias/ press/2019/6/5cfa5eb64/refugiados-y-migrantes-de-venezuela-superan-los-cuatro-millones-acnur-y.html

Alvarado, M. (26 de junio de 2020). Tratos degradantes a venezolanos retornados. Efecto cocuyo. https://efectococuyo.com/opinion/ trato-degradante-a-venezolanos-retornados/

AVN (28 de julio de 2020). En el epicentro del \#Covid19 la PNB suspendió 92 fiestas en el fin de semana. Banca y negocios. https://www.bancaynegocios.com/ en-el-epicentro-del-covid19-la-pnb-suspendio-92-fiestas-en-el-fin-de-semana/

Barrero Espinosa, C., Bohórquez Agudelo, L., Mejía Pachón, M. (2011). La hermenéutica en el desarrollo de la investigación educativa en el siglo XXI. Itinerario Educativo, 57,101-120. https://doi.org/10.21500/01212753.1436

Castoriadis, C. (1975). La institución imaginaria de la sociedad. Tusquets.

Castoradis, C. (1993). "La institución de la sociedad". En Eduardo Colombo. (Comp.). El imaginario social. Editorial Altamira, pp. 28-63.

Castoradis, C. (1997). (Trad. Luciana Volco). El imaginario social instituyente. Zona Erógena, (35, 1-9). http://www.ubiobio.cl/miweb/webfile/media/267/Castoriadis\%20 Cornelius\%20-\%20El\%20Imaginario\%20Social\%20Instituyente.pdf

Cegarra, J. (2012), Fundamentos teórico epistemológicos de los imaginarios sociales, Cinta Moebio, 43, 1-13. http://dx.doi.org/10.4067/S0717-554X2012000100001 
Centro de Derechos de Humanos. (2020). El drama de los retornados: de la revictimización a la criminalización. Universidad Católica Andrés Bello.

Cisterna Cabrera, F. (2007). Manual de metodológia de la investigación cualitatica para educación y ciencias sociales. Universidad de Bio-Bio.

Comadres Purpuras. (29 de julio de 2020). Enfermarse en Venezuela: Pánico, injusticia y desolación. Las comadres púrpuras. https://lascomadrespurpuras.com/ enfermarse-en-venezuela-panico-injusticia-y-desolacion/

Comisión Chilena de Derechos Humanos. (2020). Los derechos humanos de los migrantes. ABC Impresiones

Diccionario médico-biológico, histórico y etimológico. Pandemia En Dicciomed https:// dicciomed.usal.es/palabra/pandemia

Kirschbaum, R. (13 de abril de 2020). Coronavirus en Venezuela: Petare, el enorme barrio de Caracas donde el hambre rompe la cuarentena. Clarín. https://www.clarin.com/ mundo/coronavirus-venezuela-petare-enorme-barrio-caracas-hambre-rompe-cuarentena_0_1ZTHfBsHd.html

El Diario. (14 de mayo de 2020). Avanzan en la definición de posibles áreas de "cuarentena comunitaria” en Villa María. El Diario. https:/www.eldiariocba.com.ar/ locales/2020/5/14/avanzan-en-la-definicion-de-posibles-areas-de-cuarentena-comunitaria-en-villa-maria-20831.html

Estrada Gutiérrez, MA. (2020). Triangulación. [Diapositiva de Power Point] SlaidePlayer https://slideplayer.es/slide/16112298/

Ferrarotti, F. (2008). Historia e Historia de vida. Caracas: Centro de Investigaciones Populares.

Gaceta Oficial de la República Bolivariana de Venezuela. Ministerio del Poder Popular para la Salud. (2020) Normativa sanitaria de responsabilidad social ante la pandemia denominada Coronavirus (COVID-19), 1 de junio de 2020, N. ${ }^{\circ} 41.891$.

Gaceta Oficial de la República Bolivariana de Venezuela. (2020). Decreto N. ${ }^{\circ} 4.198,12$ de mayo de 2020, N. ${ }^{\circ} 6.535$ Extraordinario.

Marra, Y. (17 de marzo de 2020). GNB detuvo a quienes no tenían mascarilla en la avenida Fuerzas Armadas. Crónica en línea. https://cronica. uno>gnb-detuvo-quienes-tenian-mascarillas-avenida-fuerzas-armadas/ 
González Gil, L J. (14 de noviembre de 2011). El imaginario social de Cornelius Castoriadis. Una explicación sintetizada del imaginario social de Castoriadis. Antropomedia https:// www.antropomedia.com/2011/11/14/el-imaginario-social-de-cornelius-castoriadis/

Herrera Rodríguez, J. A., Guevara Fernández, G. E., Munster de la Rosa, C. H. (2015). Los diseños y estrategias para los estudios cualitativos. Un acercamiento teórico-metodológico. En Gaceta Médica, Espirituana, 17(2). 1-14. http://scielo.sld.cu/pdf/gme/ v17n2/GME13215.pdf

Interpol. (2020). Bioterrorismo. https:www.interpol.int

Mallimaci, F., Giménez Béliveau, V. (2006). Historias de vida y método biográfico. Estrategias de investigación cualitativa. Gedisa. http://jbposgrado.org/icuali/M\%E9todo\%20 biogr\%E1fico.pdf

Marra, Y. (14 de julio de 2020). Recrudece persecución a venezolanos que regresan a través de trochas por pandemia de COVID-19. Crónica-Uno. https:/cronica.uno/ recudrece-persecucion-a-venezolanos-que-regresan-a-traves-de-trochas-por-pandemia-de-covid-19/

Molina, N. (@numamolina). (15 de julio de 2020).“Un \#TrocheroInfectado es un bioterrorista que te puede quitar la vida a ti y a tus seres más queridos. Entren por los pases autorizados, bienvenidos a su patria pero sométanse a la cuarentena, no vengan a infectar a los venezolan@s" 15 de julio de 2020, 8,17 a.m. [tuit] https://twitter.com/ numamolina/status/1283375042081030146?lang=es

Navas, O M. (4 de agosto de 2020). En el barrio Unión de Petare detectan foco de covid-19. Ultimas Noticias. https://ultimasnoticias.com.ve/noticias/general/ en-el-barrio-union-de-petare-detectan-foco-de-covid-19/

Organización Panamericana de la Salud. (2020). La estigmatización social asociada a la COVID-19. https://www.paho.org/es/documentos/ estigmatizacion-social-asociada-covid-19

Orem, D. (1991). Modelo de Orem, Conceptos de enfermería en la práctica. by MosbyYear Book, Inc. cuarta edición.

Palma, M. (17 de julio de 2020). Venezuela el discurso de odio contra los retornados se afianza. La silla vacía. https://lasillavacia.com/silla-llena/red-de-venezuela/ venezuela-discurso-de-odio-contra-los-retornados-se-afianza-76628

Prado Solar, LA., González Reguera, M., Paz Gómez, N., Romero Borges, K. (2014). La teoría déficit de autocuidado: Dorothea Orem punto de partida para calidad en la atención. Universidad de Ciencias Médicas de Matanza. 
Rodríguez, D. (2020). "Plataforma patria opera con 20 millones de usuarios". http://www. minec.gob.ve/plataforma-patria-opera-con-20-millones-de-usuarios/

Sáez Baeza, C. (2005). "Seguridad ciudadana y conflictos sociales”, En Mauro Cervino (Ed.), Violencia en los medios de comunicación, generación noticiosa y percepción ciudadana, FLACSO, 21-49 pp.

Salgado Lévano, AC. (2007). Investigación cualitativa: diseños, evaluación del rigor metodológico y retos. Revista Liberabit, (13),71-78. http://www.scielo.org.pe/pdf/liber/ v13n13/a09v13n13.pdf

Soto Parra, N. (20 de julio de 2020). Acusarán de bioterrorismo a quienes regresen por pasos ilegales. Cinco 8. https://www.cinco8.com/periodismo/ acusaran-de-bioterrorismo-a-quienes-regresen-por-pasos-ilegales/

Unión Radio. (2020). COVID-19. Unionradio.net. https://unionradio.net/especiales/ covid-19-2/

Vallejo, R. (2009). La triangulación como procedimiento de análisis para investigaciones educativas. Urbe. http://ojs.urbe.edu/index.php/redhecs/article/download/84/4001 ?inline=1

Voz de América. (26 de febrero de 2020). "Cientos de peruanos marcharon en rechazo a los migrantes venezolanos". Voz de América https:/www.vozdeamerica.com/venezuela/ cientos-peruanos-marchan-rechazo-migrantes-venezolanos

Watson, K. (31 de diciembre de 2018). Venezuela, el país del que se van 5000 personas al día (y porque puede continuar el éxodo en 2019). BBC NEWS. https://www.bbc.com/ mundo/noticias-america-latina-46715015 
